\title{
CHINA'S DOMINANCE HYPOTHESIS AND THE EMERGENCE OF A TRI-POLAR GLOBAL CURRENCY SYSTEM
}




\title{
CHINA'S DOMINANCE HYPOTHESIS AND THE EMERGENCE OF A TRI-POLAR GLOBAL CURRENCY SYSTEM'
}

\author{
by Marcel Fratzscher ${ }^{2}$ \\ and Arnaud Mehl ${ }^{2}$
}

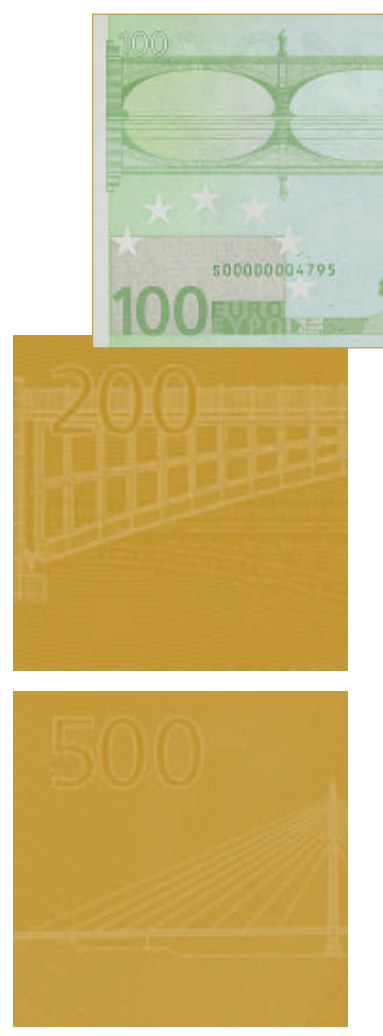

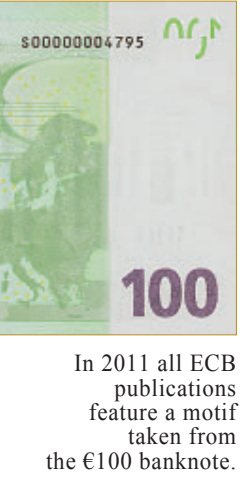

This paper can be downloaded without charge from http://www.ecb.europa.eu or from the Social Science Research Network electronic library at http://ssrn.com/abstract_id=193589I. 
(C) European Central Bank, 2011

\section{Address}

Kaiserstrasse 29

60311 Frankfurt am Main, Germany

Postal address

Postfach 160319

60066 Frankfurt am Main, Germany

Telephone

+496913440

Internet

http://www.ecb.europa.eu

Fax

+496913446000

All rights reserved.

Any reproduction, publication and reprint in the form of a different publication, whether printed or produced electronically, in whole or in part, is permitted only with the explicit written authorisation of the ECB or the authors.

Information on all of the papers published in the ECB Working Paper Series can be found on the ECB's website, http://www. ecb.europa.eu/pub/scientific/wps/date/ html/index.en.html

ISSN 1725-2806 (online) 


\section{CONTENTS}

Abstract

Non-technical summary

1 Introduction

2 Estimation and hypotheses

2.1 Unconditional analysis

2.2 Conditional analysis

3 Results

3.1 Unconditional analysis

3.2 Conditional analysis

4 Conclusions

References

Tables and figures

Appendices 


\begin{abstract}
This paper assesses whether the international monetary system is already tripolar and centred around the US dollar, the euro and the Chinese renminbi (RMB). It focuses on what we call China's "dominance hypothesis", i.e. whether the renminbi is already the dominant currency in Asia, exerting a large influence on exchange rate and monetary policies in the region, a direct reference to the old "German dominance hypothesis" which ascribed to the German mark a dominant role in Europe in the 1980s-1990s. Using a global factor model of exchange rates and a complementary event study, we find evidence that the RMB has become a key driver of currency movements in emerging Asia since the mid-2000s, and even more so since the global financial crisis. These results are consistent with China's dominance hypothesis and with the view that the international monetary system is already tri-polar. However, we also find that China's currency movements are to some extent affected by those in the rest of Asia.
\end{abstract}

JEL No: F30, F31, F33, N20

Keywords: International monetary system, exchange rates, tri-polarity, China, renminbi, US dollar, euro, German dominance hypothesis. 


\section{Non-technical summary}

The 2007-08 global financial crisis has brought the reform of the international monetary system back to the forefront of the international policy debate. Some G20 Leaders, notably from emerging economies, are questioning the configuration of the current system, which is based on a single currency, the US dollar, as the global reference currency, and the euro, as a more regional currency. Not only was the United States the origin of the financial crisis, and Europe the first continent to be engulfed in subsequent sovereign debt crises, but many link the global financial crisis to the dominant role of the US dollar, to the "exorbitant privilege" it gives to the United States, to the lack of policy discipline it encourages, and to the negative externalities it creates for the global economy.

A move to a multi-polar international monetary system is deemed by many as a distant prospect, but others expect it to unfold over the next two decades as a natural outcome of the emergence of Asia as the world economy's powerhouse. Over those years, as the story goes, the Chinese renminbi (RMB) may emerge as a truly global currency, along with the euro, while the US dollar may lose its dominant status. It is therefore unsurprising that the reform of the international monetary system has become one of the main priorities of the G20's policy agenda, with some of its members pushing actively for the emergence of a more "diversified" international monetary system that would give a greater role to the RMB or to the Special Drawing Right (SDR).

This paper assesses to what extent a tri-polar international monetary system including the US dollar, the euro and the RMB- has already emerged along with the implications of this emergence for the global economy and international financial markets. In so doing, the paper focuses on what we call "China's dominance hypothesis”, i.e. whether the RMB is already the dominant currency in Asia, exerting a large influence on exchange rate and monetary policies in the region, as much as China exerts a large influence on its neighbours through the well-known Asian production chain or Asian supply chain. Our focus on this hypothesis is rooted in the fact that there is, somewhat paradoxically, a strong sense of déja vu in today's debate on the future of the international monetary system. This debate is remarkably reminiscent of a much older one, which took place in Europe in the 1980s-90s, about the so-called "German dominance hypothesis".

We test China's dominance hypothesis by following two complementary empirical approaches. In a first step, we carry out an unconditional analysis based on a three-factor model of exchange rates, comprising a US dollar factor, a euro factor and a regional currency factor for a set of 48 currencies of advanced and emerging economies. Through the evolution of the regional FX factor, we test whether other neighbouring currencies have grown in importance in driving domestic exchange rate changes over time, and whether the regional factor has become particularly important in emerging Asia. 
Overall, we find evidence in line with China's dominance hypothesis, albeit with some qualifications, which suggests that the international monetary system is already on the verge of being tri-polar. We identify a statistically significant regional FX factor in emerging Asia's exchange rate dynamics, stronger than in any other regions of the world, a factor that has risen markedly in magnitude since China started its exchange rate reforms in 2005. Moreover, this Asian regional FX factor is found to be mainly driven by the RMB. There is, however, also evidence that causality is to some extent bi-directional and that the movements in Asia's regional factor also partly steer those of the renminbi.

As a second approach, an event-study analyses how specific shocks to China's FX regime impacts exchange rates within Asia as well as globally. The results confirm those of the unconditional analysis in that the RMB and other Asian currencies react quite similarly to such shocks, while currencies elsewhere respond very differently from the RMB. This is fully consistent with the finding of the unconditional analysis, which showed that the RMB factor loading within Asia is substantial, implying that other Asian currencies closely co-move with the RMB. The second finding is that currencies in the rest of the world do respond strongly to shocks to China's FX regime. It is in particular advanced country currencies, and foremost the euro and currencies managed vis-à-vis the euro, which are influenced by changes to the RMB regime.

The findings of the paper raise a number of questions. One of these issues concerns the optimality of FX configurations in Asia and whether the fact that countries focus their FX management vis-à-vis a currency from outside the region, such as the US dollar, is optimal or whether stronger explicit exchange rate coordination at the regional level might be beneficial. This is indeed what Europe's experience iQ the 1980s and 1990s would suggest. As China continues to reform its exchange rate regime in the years ahead, it is well possible toR that such a question could be of increasingly pressing policy interest, both for Asia and globally. 


\section{Introduction}

The 2007-08 global financial crisis has brought the reform of the international monetary system back to the forefront of the international policy debate. Some G20 Leaders, notably from emerging economies, are questioning the configuration of the current system, which is based on a single currency, the US dollar, as the global reference currency, and the euro, as a more regional currency. ${ }^{1}$ Not only was the United States the origin of the financial crisis, and Europe the first continent to be engulfed in subsequent sovereign debt crises, but many link the global financial crisis to the dominant role of the US dollar, to the "exorbitant privilege" it gives to the United States (see e.g. Gourinchas and Rey, 2007a and 2007b; Curcuru, Dvorak and Warnock, 2008), to the lack of policy discipline it encourages, and to the negative externalities it creates for the global economy.

A move to a multi-polar international monetary system is deemed by many as a distant prospect (Dobson and Masson, 2009; Cheung, Ma and McCauley, 2010; Kenen, 2011), but others expect it to unfold over the next two decades as a natural outcome of the emergence of Asia as the world economy's powerhouse (see e.g. Eichengreen, 2009 and 2010; Angeloni et al. 2011). Over those years, as the story goes, the Chinese renminbi (RMB) may emerge as a truly global currency, along with the euro, while the US dollar may lose its dominant status. It is therefore unsurprising that the reform of the international monetary system has become one of the main priorities of the G20's policy agenda, with some of its members pushing actively for the emergence of a more "diversified" international monetary system (Zhou, 2009; BRIC, 2010) that would give a greater role to the RMB or to the Special Drawing Right (SDR).

This paper assesses to what extent a tri-polar international monetary system including the US dollar, the euro and the RMB- has already emerged along with the implications of this emergence for the global economy and international financial markets. In so doing, the paper focuses on what we call "China's dominance hypothesis”, i.e. whether the RMB is already the dominant currency in Asia, exerting a large influence on exchange rate and monetary policies in the region, as much as China exerts a large influence on its neighbours through the well-known Asian production chain or Asian supply chain. ${ }^{2}$

Our focus on this hypothesis is rooted in the fact that there is, somewhat paradoxically, a strong sense of déja $v u$ in today's debate on the future of the international monetary system. This debate is remarkably reminiscent of a much older one, which took place in Europe in the 1980s-90s, about the so-called "German dominance hypothesis". The parallels that can be drawn between discussions at that time and current ones are indeed striking.

\footnotetext{
${ }^{1}$ The euro's international role, notably as a reserve or anchoring currency, is indeed most evident in the euro area's neighbouring regions; yet the euro has also global outreach in some respects, in bonds and FX markets, for instance (see ECB, 2011).

${ }^{2}$ See e.g. Feenstra and Wei (2009), Koopman, Wang and Wei (2008) or Hummels, Ishii and Yi (2001).
} 
The international monetary system was back then already dominated by the US dollar. De jure, the European currencies were all linked to each other under the European Monetary System (EMS), through a network of bilateral pegs vis-à-vis each other and in reference to the ECU (a weighted average of the participating currencies) at fixed, but adjustable, exchange rates agreed jointly. De facto, the system was markedly asymmetric (Giavazzi et al. 1986), with Germany's Deutsche Mark playing a dominant role, and other European currencies shadowing the German currency. ${ }^{3}$ The proponents of the "German dominance hypothesis" (e.g. Giavazzi and Giovannini, 1987; Giavazzi and Pagano, 1988; Gros and Thygesen, 1988; Russo and Tullio, 1988; von Hagen and Frattianni, 1990) saw this as a rather coercive arrangement, which forced the other members to follow the disciplinary, low-inflation monetary policy of the Bundesbank. Allegedly, reducing Germany's dominance through a sharing of its monetary supremacy was, in the view of several European countries, a prime motivation to create the euro (Marsh, 2009). ${ }^{4}$

Empirical tests of this hypothesis produced somewhat more nuanced results, however (e.g. de Grauwe, 1989; Cohen and Wyplosz, 1989; von Hagen and Frattianni, 1990; Frattianni and von Hagen, 1990). A result of many studies was that Germany's effect on other EMS countries was stronger, rather than the reverse effects on Germany. These countries' monetary and exchange rate policies were therefore affected both by Germany and some of the EMS countries themselves, while Germany's monetary and exchange rate policy remained independent. Strictly speaking, this rather points to a special role of Germany within the EMS than to its dominance per se. Typically, these studies used money market interest rates or money growth data as well as parameter restriction tests implied by the German dominance hypothesis and/or Granger causality tests to assess whether German interest rates or money growth led interest rates and money growth elsewhere in Europe (see e.g. von Hagen and Frattianni, 1990). ${ }^{5}$

There are important similarities with Asia's situation today. De jure, emerging Asian economies peg their currencies to the US dollar, like Europeans did to the Deutsche Mark, in what has been coined a "Revised Bretton Woods system” (Dooley, Folkerts-Landau and Garber, 2004) or an "East Asian dollar standard” (McKinnon and Schnabl, 2004). De facto, Asian economies are tightly dependant on China, by far

\footnotetext{
${ }^{3}$ The 1992-93 EMS crises, which forced Italy, Portugal, Spain, Sweden and the UK out of the system, made these asymmetries particularly apparent when Germany -hit by the unification shock- tightened monetary policy while the rest of Europe was still in recession. This episode paved the way for the creation of the euro by the end of the decade.

${ }^{4}$ For instance, Marsh (2009, p.113) notes that "in the second half of the 1980s France realised it needed political as well as technical measures to restrain Germany’s monetary predominance”, which led to early thinking about creating a single currency. He further quotes (p. 115) the late President Mitterrand as saying in 1988 that "Germany has recovered its economic power but refuses to share it".

${ }^{5}$ Some of the subsequent literature uses different techniques to gauge asymmetries in the ERM, such as non-linear forecasts when performing causality tests, with broadly similar results (e.g. Bajo-Rubio et al. 2001, Reade and Volz 2011).
} 
the region's largest economy, as European economies were on Germany. ${ }^{6}$ There are ongoing plans to strengthen monetary and financial cooperation within Asia, such as through the Chiang Mai Initiative, a regional network of currency swaps to be activated in times of crisis. The mesh of real and financial linkages woven under the Asian production chain encourages Asian economies to maintain their external competitiveness relative to China and currency stability relative to the RMB. In turn, this suggests that China's exchange rate and monetary policy, together with the reform measures taken since mid-2005 to increase exchange rate flexibility and the international role of the RMB, is likely to exert a significant -if not dominantinfluence on exchange rate and monetary policies elsewhere in emerging Asia.

By no means does this necessarily imply that the RMB's influence in the region is or will be stronger than that of the US dollar. For instance, for Europe in the 1980s, it was found that while German interest rate movements had the strongest effect on interest rates of all countries in the continent, US interest rates had also retained a significant effect. The concept of a country's dominance is a relative one, and it can still exist alongside that of another country that also exerts strong influence. This may be the case of the RMB indeed. While it may not dominate the US dollar's impact on Asian economies, it may nevertheless exert a large and rapidly growing impact on the region.

As noticeable as the parallels between Europe yesterday and Asia today may be, the China dominance hypothesis cannot be tested in a similar fashion as the German dominance hypothesis. Among the most commonly used indicators to measure a currency's international role are the amount of currency in circulation outside the issuing country, the denomination of financial assets in that currency, its use in trade transactions or share in FX reserves (see e.g. ECB 2011). However, the non-convertibility of the $\mathrm{RMB}$ and its rigid exchange rate regime make none of these indicators informative. Importantly, we stress that the aim of our analysis is not about understanding the international role of the RMB in all its dimensions. ${ }^{7}$ Our goal is rather to focus on its role as an anchoring currency and to gauge how strong the influence of China's FX policy is on other countries' FX and monetary policies, especially within the region- hence the analogy to the German dominance hypothesis.

More specifically, we need to take into account an identification challenge that arises from the RMB's de facto peg to the US dollar (or, to be more precise, snailpaced crawling peg between mid-2005 and mid-2008, as well as since mid-2010).

\footnotetext{
${ }^{6}$ Both China today and Germany twenty years ago (i.e. at the time of the European Monetary System) are (were) the largest economies in their region and a hub for regional trade. China's share in emerging Asia's output is about double that of Germany in the European Economic Community's output two decades ago (at around $50 \%$ vs. 25\%; see Chart C1). Both China today and Germany two decades ago are sizeable trading partners for their neighbours, accounting each for $10-20 \%$ of their bilateral trade (see Charts C2 and C3).

${ }^{7}$ In fact, since June 2010 Chinese authorities have undertaken several policy reforms to ultimately foster also such an international role of the RMB, such as the creation of an RMB offshore markets in Hong Kong (with additional plans to create one in London unveiled in September 2011), allowing the issuance of RMB bonds and transactions through banks, as well as a trade settlement scheme to provide incentives for some foreign trading partners to settle in RMB.
} 
Moreover, short-term interest rate or money aggregate co-movements, which were used in the German dominance hypothesis literature, are unlikely to be very informative about China's influence on the rest of Asia. China's money, credit and other financial markets remain heavily regulated, segmented or repressed. The People's Bank of China relies still largely on administrative measures and reserve requirements, aside from price-based measures. China's capital account remains largely closed, suggesting that domestic monetary and financial conditions do not cross borders easily. Lastly, and perhaps most importantly, as for most emerging markets which exhibit a fear of floating, China's main monetary policy tool is the anchoring of its currency: monetary policy is the exchange rate policy (Calvo and Reinhart, 2002).

To overcome these challenges, we test China's dominance hypothesis by following two complementary empirical approaches. In a first step, we carry out an unconditional analysis based on a three-factor model of exchange rates, comprising a US dollar factor, a euro factor and a regional currency factor for a set of 48 currencies of advanced and emerging economies. Through the evolution of the regional FX factor, we test whether other regional currencies have grown in importance in driving domestic exchange rate changes over time, and whether the regional factor has become particularly important in emerging Asia. We then link the regional factor in Asia to movements in the renminbi by means of Granger causality tests. In a second step, we conduct a conditional analysis based on shock-augmented factor model. In this analysis, we investigate the FX market reaction to official statements by Chinese authorities on exchange rate and reserve policy to identify the impact of these statements on global exchange rate constellations, while still controlling for the three FX factors of the first approach. The key strength of this complementary approach is that it allows for a clean identification of specific and exogenous RMB shocks and to measure how they affect exchange rates in the rest of Asia and beyond.

Overall, we find evidence in line with China's dominance hypothesis, albeit with some qualifications, which suggests that the international monetary system is already on the verge of being tri-polar. We identify a statistically significant regional FX factor in emerging Asia's exchange rate dynamics, stronger than in any other regions of the world, a factor that has risen markedly in magnitude since China started its exchange rate reforms in 2005. Moreover, this Asian regional FX factor is found to be mainly driven by the RMB. There is, however, also evidence that causality is to some extent bi-directional and that the movements in Asia's regional factor also partly steer those of the renminbi. China's impact on other emerging Asian countries' exchange rate policy is therefore increasingly strong and significant, but the region, taken together, still has an impact on China's exchange rate policy. Strictly speaking, this points to an important role of China in the region, but not to exclusive dominance per se.

The complementary event-study analyses how specific shocks to China's FX regime impacts exchange rates within Asia as well as globally. Two key findings stand out. First, the results confirm those of the unconditional analysis in that the 
RMB and other Asian currencies react quite similarly to such shocks, while currencies elsewhere respond very differently from the RMB. This is fully consistent with the finding of the unconditional analysis, which showed that the RMB factor loading within Asia is substantial, implying that other Asian currencies closely co-move with the RMB. ${ }^{8}$

The second finding is that currencies in the rest of the world do respond strongly to shocks to China's FX regime. It is in particular advanced country currencies, and foremost the euro and currencies managed vis-à-vis the euro, which are influenced by changes to the RMB regime. This finding is consistent with an earlier study (Fratzscher and Mehl 2009) -which focused however on the US dollar, euro and yen only- that had shown that expectations of a weakening of the RMB peg to the US dollar trigger a rebalancing of portfolios into other reserve currencies, such as the euro. As a consequence, the largest effect of those statements is found for currencies that rely on the euro as an anchor, possibly due to market expectations of diversification of China's reserves out of the US dollar into the euro, along with that of a possibly declining dominance of the US currency in the international monetary system.

Alongside the literature on the future of the international monetary system and on the "German dominance hypothesis", our paper is also linked to a nascent literature on the role of the renminbi as an anchor currency in Asia. Chen et al. (2009) and Ito (2010) apply the standard Frankel-Wei methodology (Frankel and Wei, 1994 and 2008) to find evidence that the renminbi plays a role in other East Asian currencies' de facto baskets since 2005, although the weight of the US dollar in this basket remains by far the largest. Chow (2011), by contrast, finds no evidence for such an RMB role.

The rest of the paper is structured as follows. Section 2 presents our estimation methodology and hypotheses. Section 3 reviews the empirical results. Section 4 concludes and draws policy implications.

\footnotetext{
${ }^{8}$ As a point of clarification, there is a fine but important distinction between whether policy-makers with managed exchange rate regimes allow markets to move their currencies in response to RMB policy announcements, or whether they actively pursue such movements. A case in point for the latter is the announcement by Malaysian authorities within days of China's RMB policy change in 2005 to appreciate the ringgit, explaining this decision by China's FX move.
} 


\section{Estimation and hypotheses}

This section describes the empirical methodology underlying the two complementary approaches, as well as outlines the data sources and construction.

\subsection{Unconditional analysis}

The starting point of our analysis is a three-factor global model of foreign exchange returns, in the spirit of the methodology proposed by Frankel and Wei (1994 and 2008). The three factors include a US dollar factor, a euro factor (i.e. the two main currencies of the international monetary system) as well as a regional currency factor. In its most general specification, the model is written as

$$
\Delta s_{i, t}=\alpha_{i}+\beta_{i, t}^{U S D} \Delta s_{t}^{U S D}+\beta_{i, t}^{E U R} \Delta s_{t}^{E U R}+\beta_{i, t}^{R E G} \Delta s_{i, t}^{R E G}+\boldsymbol{\delta}_{i, t} \mathbf{X}_{\mathrm{i}, \mathrm{t}}+\varepsilon_{i, t}
$$

where $s_{i, t}$ is the log of the exchange rate of country $i$ vis-à-vis the SDR at time $t ; \mathbf{X}$ a vector of control variables; the $\alpha_{i}$ country fixed effects; the various $\beta$ s and $\delta$ s (country- and time-varying) parameters; $\varepsilon$ the n.i.d. residuals; and where the superscripts $U S D, E U R$ and $R E G$ denote the US dollar, euro and regional FX factors, respectively. As is common in the literature using the Frankel-Wei methodology, we use exchange rates vis-à-vis the SDR in order to be able to estimate the importance of the US dollar for local currencies i. In extensions to this benchmark specification, we will also use bilateral US dollar exchange rates, which allows gauging the economic magnitude of the effects of movements in the regional FX factor.

Our dataset includes daily exchange rate data for 48 advanced and emerging economies over the period 1 January 1997 (i.e. just before the Asian crisis) to 28 January 2011 (see the full list of countries in Table 1). We source the data from Bloomberg and use exchange rate quotes as available at 16:00 p.m. GMT (i.e. the London fixing time, a standard industry benchmark; see Melvin and Prins, 2010). We use 2-day non-overlapping exchange rate returns to account for the fact that trading zones in Asia and the Pacific, Europe and the Western Hemisphere do not overlap (see e.g. Ehrmann, Fratzscher and Rigobon, forthcoming) and to avoid creating spurious MA(1) residual correlation if 2-day returns were overlapping. ${ }^{9}$

\section{Tables 1-2}

The regional factor is constructed as a GDP-weighted average of the currencies of a particular region, excluding country $i$ itself to ensure that it is not on

\footnotetext{
${ }^{9}$ Using 2-day returns makes no meaningful difference for the estimation of the factor model for exchange rates, as all currency values are taking at the same time, i.e. 16:00 p.m. GMT, i.e. London fixing time. However, in the robustness checks for other asset markets, such as short-term interest rates, which are available only at local closing times, the issue of non-overlapping trading times becomes relevant.
} 
both sides of Eq. (1). ${ }^{10}$ We group countries in six regions: advanced economies (the G10 floating and most liquid currencies, as well as Denmark and Iceland), emerging Asia, Latin America, the Gulf Cooperation Council (GCC), emerging Europe, and Middle-East and Northern Africa (MENA, see Table 1 for more details). ${ }^{11}$

To ensure that the factors are exogenous and to allow for their interpretability, we apply the following three identification conditions: we consider the US factor as exogenous, reflecting the US dollar's dominant role in the international monetary system; we orthogonalize the euro factor with respect to the US dollar factor by regressing the former on the latter and taking the residuals as the euro factor; and we orthogonalize the regional factor with respect to both the US and euro factors. This latter condition is especially important when considering emerging Asia, where most countries manage their currencies vis-à-vis the US dollar, as we want to make sure to identify movements in the region's currencies that are not solely due to US dollar movements. In sum, we have $s_{t}^{E U R} \perp s_{t}^{U S D}$ and $s_{t}^{R E G} \perp s_{t}^{U S D}, s_{t}^{E U R}$. Figure 1 and Figure 2 show the US factor, the euro factor as well as the regional factor (for each of our six regions) in levels (i.e. not in returns as used in the model estimations) to facilitate visual interpretation.

Figures 1-2

Table 2 reports pair-wise correlations between the three factors prior to orthogonalization, when pooling all the data for the regional factor as well as broken down by region. The rather low correlations (below 0.2 in absolute terms), and even negative one between the US and euro factors suggest that, even after orthogonalization, a significant share of euro factor-related and regional factor-related information remains to explain global FX configuration dynamics. There is some heterogeneity across regions, however. For instance, the US dollar factor is much more correlated with Asia and the GCC's regional factors (in the order of 0.5-0.7), in line with the US dollar pegs prevalent in many countries of these regions. The euro factor is strongly correlated with the advanced economies' regional factor (which likely reflects the inclusion of Iceland, Sweden and Denmark in the region, which all manage their currency heavily relative to the euro).

10 Strictly speaking, we would therefore need to denote the regional return $s_{i, t}^{R E G \backslash i}$ but we use the shortcut for notational ease. We prefer to use fixed weights (calculated as full sample period averages) rather than time-varying ones to ensure that the factor loading estimates reflect only currency movements and not changes in weights.

11 Our regional groupings draw from the IMF's World Economic Outlook (WEO) classification. Our group of "advanced economies" include those economies in our sample deemed by the WEO to be also advanced economies. Our “emerging Asia” group includes the WEO's newly industrialised Asian economies and those belonging to developing Asia according to the WEO; our "Latin America" group those belonging to "Latin America and the Caribbean" in the WEO; our "emerging Europe" group those that are classified by the WEO into "Central and Eastern Europe" as well as into the "Commonwealth of Independent States"; last, we have singled out from our "Middle-East and Northern Africa” group (akin to the WEO’s own group) the Gulf Co-operation Countries because of their strict US dollar pegs. 
Our test of China's dominance hypothesis relies on two nested hypotheses. We first test for the existence of a regional FX factor in emerging Asia and whether it has grown in economic importance after the onset of China's exchange rate reforms in 2005, i.e. our null hypotheses are

$$
H_{0}: \hat{\beta}_{i}^{R E G}=0 \text { and } H_{0}^{\prime}: \hat{\beta}_{i \mid t>2005}^{R E G} \leq \hat{\beta}_{i \mid t \leq 2005}^{R E G}
$$

for $i \in$ emerging Asia. Second, and conditional on this, we test whether Asia's regional factor (excluding the renminbi) is driven by movements in the renminbi and not vice-versa, by means of Granger causality tests, i.e. in the VAR model

$$
\left\{\begin{array}{c}
\Delta s_{t}^{R E G \backslash R M B}=\sum_{k=1}^{n} \beta_{k}^{1} \Delta s_{t-k}^{R E G \backslash R M B}+\sum_{k=1}^{n} \rho_{k}^{1} \Delta s_{t-k}^{R M B}+v_{t}^{1} \\
\Delta s_{t}^{R M B}=\sum_{k=1}^{n} \beta_{k}^{2} \Delta s_{t-k}^{R E G \backslash R M B}+\sum_{k=1}^{n} \rho_{k}^{2} \Delta s_{t-k}^{R M B}+v_{t}^{2}
\end{array}\right.
$$

for $R E G \in$ emerging Asia and lag order $n$, we use a standard $F$-test to test the two following null hypotheses

$$
H_{0}^{\prime \prime}: \hat{\rho}_{1}^{1}=\ldots=\hat{\rho}_{n}^{1}=0 \quad \text { and } \quad H_{0}^{\prime \prime \prime}: \hat{\beta}_{1}^{2}=\ldots=\hat{\beta}_{n}^{2}=0
$$

\subsection{Conditional analysis}

The three-factor model of equation (1), on which the tests of China's dominance hypothesis presented so far are based, is informative about co-movements and correlations across global foreign exchange returns. However, such a model is mute about the ultimate source of these co-movements, which can be identified only indirectly. A more direct way to test for China's dominance hypothesis is therefore to analyze the transmission of specific shocks to China's FX regime, which can be clearly identified. This allows identifying the direction of causality and the origin of co-movements with the added advantage to more cleanly trace the effect of a particular shock through global foreign exchange markets.

We therefore conduct a complementary analysis based on a shock-augmented factor model. The aim is to carry out an event-study to exploit the global FX market reaction to official statements made by Chinese authorities on exchange rate and reserve policy so as to identify their exchange rate impact, in particular for emerging Asian currencies. The key strength of this approach (see also Fratzscher, 2008a, 2008b, 2009; Fratzscher and Mehl, 2009) is that it allows for a clean identification of specific and exogenous RMB shocks and to measure how they affect the rest of Asia. Our hypothesis is that if market participants consider such statements as credible, they 
can be expected to have a depreciating effect on the US dollar against the euro and against currencies that use the US dollar as an anchor, like those of emerging Asia. ${ }^{12}$

This prior is based on the following motivation. Chinese official statements pointing to a diversification of reserves out of US dollars or to the desirability of an appreciation of the RMB against the US dollar should weaken the US dollar against other major currencies primarily through a portfolio balance channel. This would imply indeed that China reduces its purchases of US dollar-denominated securities and, in turn, its demand for US dollars. This channel has been shown to have played some role in the past for foreign exchange market intervention by central banks (see e.g. Branson, 1977; Dominguez and Frankel, 1993). The effect of official statements may also occur through a coordination channel (Sarno and Taylor, 2001) as they may trigger and help coordinate expectations among market participants. In particular, statements interpreted by markets as suggesting a weakening of the strong US dollar focus of China's exchange rate policy might be interpreted as a signal that relative demand for global currencies could fundamentally change and, in particular, that the role of the US dollar in the international monetary system could decline.

Dollar-pegged currencies in emerging Asia should also appreciate relative to the US dollar for two related reasons. First, market participants might interpret official statements as a signal that, should China decouple from the US dollar, the rest of Asia could well de-couple too. Second, official statements that point to an appreciation of the RMB against the US dollar encourage other emerging Asia economies to let their currencies appreciate in turn, to stabilise their relative competitiveness within the Asian production chain.

Our conditional model is an extended version of the model we use for the unconditional analysis, i.e.

$$
\Delta s_{i, t}=\alpha_{i}+\beta_{i, t}^{I O} I O_{t}+\beta_{i, t}^{U S D} \Delta s_{t}^{U S D}+\beta_{i, t}^{E U R} \Delta s_{t}^{E U R}+\beta_{i, t}^{R E G} \Delta s_{i, t}^{R E G}+\boldsymbol{\delta}_{i, t} \mathbf{X}_{\mathbf{i}, \mathbf{t}}+\varepsilon_{i, t}
$$

where we have added $I O$, a $[-1 ; 0 ;+1]$ indicator variable for Chinese statements on the exchange rate regime or reserves. Appendix B provides a theoretical basis for such a model, based on the microstructure literature of FX markets, and more specifically the literature on announcement effects and asset prices (e.g. Andersen et al. 2003, Blinder et al. 2008).

\footnotetext{
${ }^{12}$ Our earlier research suggests that statements of Chinese authorities should be taken seriously indeed. In a previous paper (Fratzscher and Mehl, 2009), which had focused on their impact on the US dollar, euro and yen, we had found that, on average, statements by emerging market authorities lead to an appreciation of $0.25 \%$ of the euro against the US dollar and of $0.15 \%$ of the yen against the US dollar on the day they occur. This is in fact fairly large: about half the estimated average impact of the ECB President's exchange rate statements on the USD/EUR (see also Fratzscher, 2008a); and about the same estimated average impact of Japan's Minister of Finance's statements on the JPY/USD.
} 
Our test of China's dominance hypothesis consists in testing whether the official statements lead to an appreciation of emerging Asian currencies which is similar to the RMB response itself, i.e. policy-makers in other Asian economies are willing to let their currencies move in response to such shocks, but only to the extent that their own currencies remain relatively stable - or do not appreciate overly fastagainst the RMB:

$$
H^{*}{ }_{0}: \hat{\beta}_{i}^{I O}=\hat{\beta}_{R M B}^{I O} \leq 0
$$

for $i \in$ emerging Asia. Note that our prior is to have a negative sign on the coefficient, which implies an appreciation response, as the currency is defined as LC/SDR. An open issue is whether and how other, non-Asian currencies may respond to such statements about China's FX regime. If markets expect that a change to the RMB regime may imply e.g. a significant diversification of reserves out of the US dollar, it may well be that the euro and other reserve currencies -and currencies comoving with these reserve currencies- are relatively more sensitive to such statements than the RMB or other Asian currencies. This is the main hypothesis of interest in the empirical section presented below.

\section{Data on Chinese statements}

In order to take the model to the data, we compile a novel database of statements of official statements by Chinese authorities on exchange rate and reserve policy, which builds partly on the database used in Fratzscher and Mehl (2009). We collect statements by the People's Bank of China (PBC) Governor, People's Republic President and Premier as well as by other PBC officials, including the Head of the State Administration of Foreign Exchange (SAFE) and other Chinese officials who have occasionally -albeit more rarely- expressed public views on the renminbi and/or on the composition of China's reserves. ${ }^{13} \mathrm{~A}$ list of those policy-makers is provided in Table I in Appendix A.

Public statements generally stem from three sources: speeches, interviews and public testimonies. In order to ensure that these statements were also available to market participants in financial markets, one of the most commonly used wire services, Reuters News, was chosen to extract relevant news releases for the period 1 January 1997 to 28 January 2011. These releases were obtained through Factiva. Reuters News has the advantage of being one of the most comprehensive wire services, reporting on and disseminating all major news in a timely and truly global fashion, usually within a short timeframe after a public announcement. It is also among those providers which receive greatest attention among traders and investors

\footnotetext{
${ }^{13}$ For instance, these include officials from Chinese Investment Corporation, the institution which along with SAFE- is in charge of managing China's reserve assets.
} 
globally. This allows using daily data to analyse the impact of statements on FX markets. $^{14}$

In selecting the statements, the search criteria for those relating to China's exchange rate policy were:

(a) the name or the title of the policy-maker,

(b) the word "exchange rate" or "renminbi" or "RMB" or "yuan" and

(c) the words "stable" or "stability" or "flexible" or "flexibility" or "dollar" or "peg”.

Likewise, the search criteria for statements on China's reserve policy were:

(i) the name or the title of the policy-maker,

(ii) the word "reserves" and

(iii) the words "composition" or "diversification" or "portfolio" or "rebalancing” or “dollar”.

Clearly, a crucial issue is how to classify the statements in terms of both content and meaning. Statements $I O$ are categorised as advocating that the US dollar peg will be relaxed either to let the RMB appreciate or depreciate or that the peg will be maintained. Moreover, statements referring to reserve allocation are classified as either suggesting diversification away from the US dollar, diversification into the US dollar or that the composition of reserves remains unchanged:
$I O_{t}=\left\{\begin{array}{l}+1 \\ 0 \\ -1\end{array}\right.$
US dollar peg relaxed to appreciate
Diversification out of the US dollar
US dollar peg maintained
Reserve composition unchanged
US dollar peg relaxed to depreciate
Diversification into the US dollar

Table II in Appendix A contains examples of statements for each of those categories. The classification is a judgmental one and clearly in some cases difficult to make. Three points should be noted. First, the classification is done in a mechanical way, i.e. all statements are classified based on their language content, and by at least

\footnotetext{
${ }^{14}$ Arguably an alternative might be to use intraday data together with the time stamps corresponding to the statements of our database. However, using intraday data is not a feasible option for improving our identification scheme because the reports of Reuters News are the articles summarising a particular statement by a policy-maker. These articles may come as soon as 20 minutes after a particular statement, or they become available several hours later in the day. Hence we cannot measure the highfrequency market response of a statement because no data is available for the initial "snaps" (i.e. realtime reporting of headlines containing at most a few words), which may occur within seconds after a statement.
} 
two persons. Second, the only statements that are not classified and left out are those that occurred on release days of relevant macroeconomic data or monetary policy meeting days, which could have a dominant effect on those days. Third, the advantage of using newswire services is that an interpretation of the statements is very often provided by professionals who are aware of nuances and experienced in interpreting them.

Two additional caveats should yet be borne in mind. A first caveat is that newswire reports may not reflect the true intention of policy-makers. Moreover, some public statements may not be covered hence the list of statements is only a list of statements as reported by Reuters, and not necessarily a complete one. This is a relatively minor drawback, however. As the objective of our conditional analysis is to analyse the reaction of market participants to policy-makers' communication, it seems sensible indeed to focus only on those statement that actually become available to market participants and, again, Reuters News is among those providers that receive greatest attention among traders and investors.

Table III in Appendix A provides a summary of the around 320 statements we collected for the period 1 January 1997 to 28 January 2011. The bulk of these statements (269, or about $80 \%$ ) are on the exchange rate regime. In terms of meaning and content, about $60 \%$ of the statements repeat a mantra that the exchange rate regime will remain unchanged and are classified as neutral; about 30\% are classified as signalling that the reference to the US dollar will be relaxed to let the RMB appreciate; about $10 \%$ are classified as signalling that the reference might be relaxed to let the RMB depreciate (e.g. when uncertainties mounted in the wake of the Asian crisis as to whether the Chinese renminbi might be devalued). Statements on reserve policy reserve are fewer (about 50) than those on exchange rate flexibility. More than half thereof signal diversification away from the US dollar. In terms of authorship, about $40 \%$ of the statements were made by the Governor of the People's Bank of China and $20 \%$ by the Chinese Premier, while the President of the People's Republic and the Head of SAFE speak much less frequently (each account for less than $10 \%$ of the statements).

Figure 3

To further give an intuition of the data, Figure 3 plots the statements by Chinese officials together with the RMB/USD over time. Statements by Chinese authorities were markedly more frequent in the aftermath of the Asian crisis, in 19972000, when the debate about a possible devaluation of the renminbi mounted, between 2004/5 (start of the exchange rate reform) and mid-2008 (start of the global financial crisis and de facto re-pegging of the renminbi to the US dollar), as well as since late 2009 (eruption of sovereign debt crises). 


\section{Results}

This section presents the empirical results, starting with those for the unconditional analysis, then proceeding with the conditional analysis, and concluding with various extensions and robustness checks.

\subsection{Unconditional analysis}

Table 3 reports baseline estimates for the three-factor exchange rate model of equation (1), using a pooled OLS estimator (columns (1) to (3)) and a fixed effect estimator (columns (4) to (6)). We consider model specifications including only the factors and also including controls, namely the change in oil prices, global liquidity conditions (as proxied by the TED spread, i.e. the difference between short-term US interbank and T-bill rates) and risk (as proxied by the VIX index, a measure of implied volatility of S\&P 500 index options). ${ }^{15}$ We correct standard errors for heteroscedasticity and clustered heterogeneity.

\section{Tables $3-4$}

A first key insight from Table 3 is that the US factor explains the bulk of global FX dynamics. The US factor loading is the largest of the three factors, at around 0.4 (i.e. a 1\% depreciation of the US dollar vis-à-vis the SDR is associated with an average $0.4 \%$ depreciation of the sample's currencies vis-à-vis the SDR). This reflects the US dollar's dominant role in the international monetary system. Both the euro and regional factors are of a smaller magnitude, with a loading estimate of about 0.14-0.17 (i.e. less than half that of the US factor), pointing to a more modest importance for exchange rate dynamics globally. Depending on the specification, adjusted- $R^{2}$ s are in the order of $7 \%-11 \%$, which is fairly satisfactory when considering the high data frequency. The results are also very robust across specifications and they are not altered when adding controls or country effects. The latter, in particular, are insignificant and only explain a very small share of the data's variance (as indicated by the $\rho$-statistics reported in the bottom row of Table 3).

Another important aspect is the marked increase of the regional factor's importance over time. Table 4 presents estimation results for two sub-periods: (i) before the start of China's exchange rate reform in 2005 and (ii) after the start of the reform. Strikingly, the estimated regional factor loading more than quadruples between these two periods, from about 0.07 before 2005 to over 0.30 afterwards. This underscores the growing importance of the regional dimension in global exchange rate dynamics, an aspect of key importance for Asia.

Table 5, Figure 4

\footnotetext{
${ }^{15}$ Data for the control variables are taken from Bloomberg.
} 
Do the factor model estimates vary between advanced and emerging economies and, within emerging economies, across regions? Table 5 presents estimates broken down by country groups and regions. When restricting the estimation to advanced economies, the factors are found to be mostly insignificant (or barely significant in the case of the euro factor), in line with the fact that most of these currencies are floating. ${ }^{16}$ Within the emerging economies, the US factor is found to be most important for emerging Asia, Latin America and the GCC, with loadings of about $0.6,0.8$ and 1 , respectively, which mirrors the strong orientation of these regions' currencies to the US dollar. In turn, the importance of the euro factor is strongest for emerging Europe, with a loading estimate of 0.3, in line with the euro's important role in the region, which itself rests on strong institutional, trade and financial linkages between the euro area and its Central and Eastern European neighbours.

Importantly, the regional factor is statistically significant for emerging Asia, a piece of evidence in line with China's dominance hypothesis, which also implies that the null hypothesis $H_{0}$ of Eq. (1bis) can be rejected. Emerging Asia's regional factor is also by far the largest in magnitude across all regions, with an estimated loading of over 0.2 , underscoring the strong regional orientation of exchange rate policy in the area, under the "East Asian dollar standard" and the "Asian production chain". Moreover, the model for emerging Asia has a remarkably good fit, with an adjusted $R^{2}$ of over $20 \%$, which is better only for the GCC economies (for which the model has perfect fit, which is due to these countries' stringent US dollar pegs).

In line with this evidence, Figure 4 shows that there is a significant degree of heterogeneity in regional exposures across our sample's 48 currencies, but that the regional factor is especially important for emerging Asian currencies. The figure, which plots the distribution of the regional factor loadings estimated for all of the currencies, suggests that this distribution is very heterogeneous. Some currencies react almost one-to-one with the regional factor; others are unaffected by regional currency dynamics, with loadings close to zero; and a few others move in a direction systematically opposite to that of the currencies of their region, with a negative loading estimate. The estimates for the emerging Asian currencies, which are indicated by the red lines in the figure, confirm that the regional dimension is of key importance for these currencies. Arguably, China and Hong Kong have regional factor loadings that are virtually close to zero (due to their hard pegs to the US dollar). But India has a loading of about 0.1 (close to the pooled sample estimate), while that of Indonesia, Singapore and Taiwan are much higher (at about 0.3, i.e. over twice the pooled sample estimate) and that of Taiwan, Thailand; Philippines; Malaysia and Korea are among the highest in the sample (at about 0.5).

Tables $6-7$

\footnotetext{
${ }^{16}$ The statistical significance of the euro factor might be due to the fact that our group of advanced economies also includes Sweden, Denmark and Iceland, which all manage (more or less heavily) their currencies vis-à-vis the euro.
} 
Considering now emerging Asia more specifically, Table 6 presents evidence that the regional factor has grown in economic importance over time, another piece of evidence consistent with China's dominance hypothesis, which also implies that the null hypothesis $H_{0}^{\prime}$ of Eq.(1bis) can be rejected. The table reports regression results when restricting the sample to emerging Asia and for two sub-periods (before and after 2005). Strikingly, the regional factor loading estimate after the start of China's exchange rate reform in 2005, at 0.25, is about one-third higher than that before 2005. This is supportive of the view that emerging Asia's policy-makers pay more attention to regional currency developments as China gradually strengthens the flexibility of its exchange rate regime.

Table 7 presents even more direct evidence of the growing role played by the renminbi in the region. It reports estimates based on a slightly modified version of the factor model where the regional factor is replaced with a "China factor", i.e. the $\mathrm{RMB} / \mathrm{SDR}$ exchange rate, which we orthogonalize with respect to the US factor (and the euro factor) to identify renminbi movements that are not purely driven by the US dollar. The estimates are reported for various sub-periods: before and after 2005; prior to the outbreak of the global financial crisis (2005 to 2007); during the global financial crisis (2007 to 2008); and since the onset of the recovery in emerging Asia (since 2009). China is excluded from the estimations so as not to have it on both sides of the regression. What is conspicuous about the results is that the China factor is neither statistically significant over the full estimation period nor over all sub-periods up to the global financial crisis. But since emerging Asia started to recover in 2009, the China factor is both statistically significant and very important in terms of economic magnitude, with a loading of about 0.15 , i.e. several times larger than the pre-crisis estimate. Again, this is supportive of the view that policy-makers and/or markets in emerging Asia are paying much greater attention to developments in the renminbi for the valuation of other regional currencies since the crisis.

Although the role of the RMB factor is increasing markedly over time, it is not dominant in economic magnitude (while the US dollar factor is). It is worth stressing again, however, that the concept of a country's dominance is a relative one, and it can still exist alongside that of another country that also exerts strong influence. This may be the case of the RMB indeed. While it may not dominate the US dollar's impact on Asian economies, it may nevertheless exert a large and rapidly growing impact on the region. $^{17}$

\section{Table 8}

Having established that a regional factor explains currency movements significantly in emerging Asia and increasingly so since China started to reform its exchange rate regime in 2005, we now test whether this regional factor is driven by the renminbi and not vice-versa. This is taken up in Table 8, which reports Granger

\footnotetext{
${ }^{17}$ Also as aforementioned, it was similarly found for Europe in the 1980s that while German interest rate movements had the strongest effect on interest rates of all countries in the continent, US interest rates had also retained a significant effect.
} 
causality test results based on a bi-variate VAR for emerging Asia. The VAR includes 2-day (non-overlapping) returns for the RMB/SDR and the regional factor (excluding China) and up to 3 lags. The table shows the $p$-value of the corresponding $F$-tests for various sub-periods.

Overall, there is significant evidence that the RMB causes movements in Asia's regional factor, in line with China's dominance hypothesis since the start of China's exchange rate reform in 2005. The null that it does not (i.e. $H_{0}^{\prime \prime}$ in Eq. (1ter)) is rejected for the period after 2005, but not before (see upper quadrant of Table 8). This again suggests that it is only after China embarked on reforms that the renminbi gained influence on the rest of emerging Asia's currencies. Noticeably, the null is most strongly rejected in post-crisis data, i.e. after the onset of the recovery in emerging Asia in 2009. This further confirms that the global financial crisis was a major turning point in strengthening the RMB's role in the region.

A further interesting finding is that the renminbi is not immune from influences stemming from the rest of Asia. There is evidence that causality is bidirectional. In other words, movements in Asia's regional factor also cause those of the renminbi to some extent. We cannot reject the null that they do not indeed (i.e. $H_{0}^{\prime \prime \prime}$ in Eq. (1ter)) either before 2005 nor after (see the lower quadrant of Table 8). We can only do so during the acute phase of the crisis (2007-2008), perhaps because of China's de facto re-pegging to the US dollar in the middle of 2008. All in all, these results suggest that China's dominance in emerging Asia remains weaker so far than that of Germany on Europe two or three decades ago. China's impact on other emerging Asian countries' exchange rate policy is strong and significant, but the region, taken together, also has an impact on China's exchange rate policy. Strictly speaking, this points to an important role of China in the region, but not to dominance per se.

\subsection{Conditional analysis}

The evidence on the RMB's role in emerging Asia we have presented thus far is only indirect, however. To gauge more directly the impact of China's currency in the region, we conduct a complementary analysis based on an event-study that exploits the FX market reaction to official statements on exchange rate and reserve policy made by Chinese authorities. As discussed above, this allows for a clean identification of exogenous RMB-specific shocks and to trace their effect through global foreign exchange markets, notably in Asia. Our hypothesis remains that if market participants consider such statements as credible, they can be expected to have a depreciating impact on the US dollar against the euro and other reserve currencies. Moreover, one would expect also other Asian currencies to appreciate against the US dollar, but a regional dominance of the RMB should imply that such an appreciation is broadly similar to that of the RMB itself, as policy-makers in Asia try to stabilise the movements of their currencies relative to that of the RMB. 
Table 9 reports estimates for the full sample of the conditional model of equation (2), using a pooled OLS estimator (columns (1) to (3)) and a fixed effect estimator (columns (4) to (6)). There is strong evidence that RMB shocks impact global exchange rate configurations in line with our theoretical prior. A statement pointing to a relaxation of China's peg to the US dollar or to a diversification of China's reserves away from the US dollar leads to a statistically significant appreciation of the currencies in our sample relative to the SDR basket, i.e. including the US dollar, of $0.1 \%$ on average, on the day the statement occurs. This result is very robust across specifications and is not altered when adding controls or country effects. Country effects, in particular, are again insignificant, and explain an infinitesimally small share of the data's variance (as indicated by the $\rho$-statistics). Moreover, the factor loadings of the three FX factors remain quasi identical to those estimated under the unconditional model.

The economic importance of RMB shocks for overall FX markets has increased somewhat over time, as shown by Table 10, which reports that the estimated impact of Chinese statements rises from -0.08 before 2005 to -0.11 afterwards. The impact of the RMB shocks yet varies appreciably in magnitude across country groups and regions (see Table 11). It tends to be stronger for advanced economies (with an estimate of about -0.14) than for EMEs (with an estimate of about -0.09), perhaps because of the latter's more rigid exchange rate regimes. Within EMEs, the estimated impact is also stronger for emerging Europe (at about -0.15) than for Latin America or Asia (at about -0.11 and -0.08 , respectively). The strong effect found for emerging European currencies might reflect the fact that they are often managed vis-à-vis the euro which, in line with portfolio balance models predictions, could be markedly impacted if market participants would expect China to de-couple from the US dollar.

\section{Figure 5}

Most importantly, Figure 5 shows that the responses of Asian currencies are more similar to that of the RMB itself than the responses of currencies of advanced economies or other EME regions (with the exception of the Gulf Cooperation Council countries, which have strict peg to the US dollar). This provides some general confirmation for hypothesis (2bis). However, Figure 5 also indicates that Asian currencies generally react stronger than the RMB itself. One interpretation is that statements by Chinese authorities trigger market expectations that induce strong appreciation pressures in other countries, while contemporaneously Chinese authorities are able to keep the RMB relatively more stable (which may be more feasible for Chinese authorities, given the non-convertibility of the RMB, than for policy-makers with more open FX markets).

\section{Robustness and extensions to the conditional analysis}


We now turn to a number of extensions and robustness tests. Focusing more narrowly on emerging Asia, Table 12 shows that the effect of RMB shocks on the region's currencies has grown markedly in economic importance since China embarked on exchange rate reforms in 2005. The estimated shock impact after 2005, at -0.09 , is roughly three times larger than before 2005 (see Table 12).

Table 12

We extend the conditional analysis in various directions in order to gauge the robustness of the findings and also to draw out more about the economic relevance of the effects of the RMB. We first use the US dollar rather than the SDR basket as numéraire, in order to make the parameter estimates readily interpretable. Table 13 reveals that the parameter estimates double from -0.10 before 2005 to almost -0.20 after 2005. In other words, a statement pointing to a relaxation of China's peg to the US dollar or to a diversification of China's reserves away from the US dollar leads to an appreciation of emerging Asian currencies of $0.2 \%$ on average vis-à-vis the US dollar, on the day the statement occurs.

We find a similarly strong post-2005 increase in economic magnitude when using forward exchange rates (non-deliverable forward contracts, NDFs), which can be taken as a proxy of market expectations regarding future exchange rates (see Table 14). Considering also the evidence after 2005 in more detail, it is striking that the impact of RMB shocks is strongest after the start of emerging Asia's recovery in 2009, with an order of magnitude that is almost four times larger than before 2005 (Table 15).

Tables $13-15$

These findings give further support to the view that policy-makers in emerging Asia have been paying much greater attention to developments in the renminbi since the crisis. They are in line with the existence of both a portfolio balance channel and a signalling channel, in which market participants regard Chinese official statements as a signal that, should China decouple from the US dollar, the rest of Asia could may decouple too. Moreover, the results are supportive of the view that official statements pointing to an appreciation of the RMB against the US dollar encourage other emerging Asian economies to let their currencies appreciate in turn, so as to stabilise their relative competitiveness within the "Asian production chain”.

Table 16

As a final point, Table 16 reports pooled OLS estimates of potential determinants of the heterogeneity in the country-specific elasticities with respect to RMB shocks shown in Figure 5 and Table 11. We therefore take all the betas in a cross-section and try to explain them by looking at four specific determinants: trade integration with China (i.e. both the share of exports to China in total exports and that of imports from China in total imports); financial integration with China (i.e. the share 
of portfolio investments in China in total portfolio investments); the flexibility of the exchange rate regime; as well as dummies for countries belonging to what we consider as the "dollar bloc" (emerging Asia and the GCC) and those belonging to what we call the "euro bloc" (emerging Europe) ${ }^{18}$

Two results are worth stressing. Higher exchange rate flexibility tends to increase $\hat{\beta}_{i}^{I O}$ and is associated with a stronger appreciation of the exchange rate as a result of an RMB shock. This may apply in particular to currencies such as the euro and other European currencies, which have been shown above to respond strongly to Chinese statements on the RMB. Moreover, the anchor currency matters. The currencies of the countries belonging to the US dollar bloc tend to appreciate less to an RMB shock, while those belonging to the euro bloc tend to appreciate more, a result that is fairly robust across specifications. This further underscores the possible existence of a portfolio balance channel and a signalling channel, as well as the role played by market expectations of diversification of China's reserves out of the US dollar into the euro, along with that of a possibly declining dominance of the US currency in the international monetary system.

We stress that this final part of the analysis on the determinants is merely suggestive, as other channels and mechanisms may be at work as well. The point is rather to show that the cross-sectional heterogeneity in the responses to Chinese FX statements has an underlying economic rationale that is indeed related to the choice of exchange rate regimes and economic fundamentals of countries. Overall, the findings point not only to a rising role of the RMB in determining exchange rates of other Asian countries, but also to a global influence of the RMB in affecting global FX configurations.

\section{Conclusions}

This paper has presented empirical evidence consistent with China's dominance hypothesis, suggesting that the international monetary system is already on the verge of being tri-polar, with the US dollar as global currency, and both the euro and the Chinese renminbi playing an important role for regional currencies. China's exchange rate policy is found to already exert a strong and growing influence on other emerging Asian economies' exchange rate policies since 2005, and even more so since the global financial crisis.

However, exchange rate developments in China do not seem entirely immune from influences from the rest of Asia: we have also uncovered evidence of bidirectional causality and that Asian currency movements also drive those of the

\footnotetext{
18 Data for trade and financial integration are taken from the IMF's WEO and CPIS databases. Exchange rate regimes are classified according to Reinhart and Rogoff (2004) in line with the 2008 updates of Ilzetzki, Reinhart and Rogoff, and with following coding: 1 = dollarisation/euroisation or hard peg; 2-3 = managed float; 4 = free float. The estimates of Table 16 are obtained using the SDR as numéraire. Quasi similar results are obtained when using the US dollar as numéraire.
} 
renminbi, albeit to a lesser extent. All in all, these results suggest that China's dominance in emerging Asia remains weaker so far than that of Germany on Europe two or three decades ago since Germany's monetary and exchange rate policy was found never to be influenced by that of other European countries at that time.

Looking ahead, many open questions remain. First, we have emphasised that our analysis is not about all the facets of the international role of the RMB - i.e. the use the RMB in real or financial transactions, or in FX reserve holdings - but rather about its emerging role as an anchor currency, i.e. the influence of China's FX policy on global FX configurations and in particular on the Asian region, akin to the debate about the importance of German policy for the EMS in the 1980s and 1990s. A rising international role of the RMB, as envisaged and currently actively pursued by Chinese authorities, may well increase this influence of RMB policy further in the years ahead.

Another issue concerns the optimality of FX configurations in Asia and whether countries should focus their FX management vis-à-vis a currency from outside the region, such as the US dollar, is optimal or whether stronger explicit exchange rate coordination at the regional level might be beneficial. This is indeed what Europe's experience is the 1980s and 1990s would suggest. As China continues to reform its exchange rate regime in the years ahead, it is well possible to that such a question could be of increasingly pressing policy interest, both for Asia and globally. 


\section{References}

Andersen, T., T. Bollerslev, F. Diebold and C. Vega (2003), "Micro Effects of Macro Announcements: Real-Time Price Discovery in Foreign Exchange," American Economic Review, vol. 39(1), pp. 38-62.

Angeloni, I, A. Bénassy-Quéré, B. Carton, Z. Darvas, C. Destais, L. Gauvin, J. PisaniFerry, A. Sapir, S. Vallee (2011), Reforming the international monetary system: options and implications, joint Bruegel-CEPII report, April 2011.

Bajo-Rubio, O., S. Sosvilla-Rivero, F. Fernandez-Rodriguez (2001), “Asymmetry in the EMS: New Evidence Based on Non-Linear Forecasts,” European Economic Review, pp. 451-473.

Blinder, A., M. Ehrmann, J. de Haan, M. Fratzscher and D.-J. Jansen (2008), “Central Bank Communication and Monetary Policy: a Survey of Theory and Evidence”, Journal of Economic Literature, vol. 46(4), pp. 910-945.

BRIC Heads of States and Governments (2010), Joint Statement at the BRIC countries summit in Brasília, 15 April 2010.

Branson, W.H. (1977), "Asset Markets and Relative Prices in Exchange Rate Determination,”, Sozialwissenschaftliche Annalen, Band 1.

Calvo, G. and C. Reinhart (2002), "Fear of Floating," Quarterly Journal of Economics, Vol. 107(May), pp. 379-408.

Chen H., W. Peng and C. Shu (2009), "The Potential of the Renminbi as an International Currency,” BIS Asian Research Program Research Papers, February 2009.

Cheung, Y-W., M. Guonan, and R. N. McCauley (2010), "Renminbising China's Foreign Assets”, CESIfo working paper.

Chow, H. K. (2011). "Is there a Yuan Bloc in East Asia?” Singapore Management University, mimeo, May 2011.

Cohen, D. and C. Wyplosz (1989), 'The European Monetary Union-An Agnostic Evaluation,' in R. C. Bryant, D. A. Currie, J. A. Frenkel, P. R. Masson. and R. Portes, eds, Macroeconomic Policies in an Interdependent World. Washington DC: International Monetary Fund.

Curcuru, S. E., T. Dvorak and F. Warnock (2008), "Cross-Border Returns Differentials,” Quarterly Journal of Economics, 123(4), pp. 1495-1530.

De Grauwe, P. (1989), “Is the European Monetary System a DM-Zone?” CEPR Working Paper, No. 297.

Dobson, W and P. Masson (2009), "Will the RMB Become a World Currency?" China Economic Review, No. 20, pp. 124-135.

Dominguez, K. and J. Frankel (1993) "Does Foreign Exchange Intervention Matter? The Portfolio Effect,” American Economic Review, 83 (5), pp. 1356-1369.

Dooley, M. P., D. Folkerts-Landau and P. Garber (2004), "The Revised Bretton Woods System,” International Journal of Finance and Economics, 2004, Vol. 9(4) October, pp. 307-313.

Eichengreen, B. (2009), “The Dollar Dilemma: The World's Top Currency Faces Competition”, Foreign Affairs, 888 (5), pp. 53-68. 
Eichengreen, B. (2010), Exorbitant Privilege - The Rise and Fall of the Dollar and the Future of the International Monetary System, Oxford University Press, December 2010.

Ehrmann, M., M. Fratzscher and R. Rigobon, "Stocks, Bonds, Money Markets and Exchange Rates: Measuring International Financial Transmission,” Journal of Applied Econometrics, forthcoming.

European Central Bank (2011). Annual Review of the International Role of the Euro, Frankfurt, July 2011.

Feenstra, R. \& S.-J. Wei (2009), “Introduction to 'China's Growing Role in World Trade',” NBER Working Papers, No. 14716.

Frankel, J. and S.-J. Wei (1994), "Yen Bloc or Dollar Bloc: Exchange Rate Policies of the East Asian Economies," in T. Ito and A. Krueger (eds) Macroeconomic Linkages, University of Chicago Press, Chicago.

Frankel, J. and S.-J. Wei (2008), "Estimation of De Facto Exchange Rate Regimes: Synthesis of the Techniques for Inferring Flexibility and Basket Weights," NBER Working Paper, No. 14016.

Fratianni, M. and J. von Hagen (1990), “German Dominance in the EMS: The Empirical Evidence,” Open Economies Review, 1, pp. 67-87.

Fratzscher, M. (2008a), “Communication and Exchange Rate Policy,” Journal of Macroeconomics, 30, pp. 1651-1672.

Fratzscher, M. (2008b), "Oral Interventions vs. Actual Interventions in FX markets An event-study approach,” Economic Journal, 118 (July), pp. 1079-1106.

Fratzscher, M. (2009), "How Successful is the G7 in Managing Exchange Rates?" Journal of International Economics, 79, pp. 78-88.

Fratzscher, M. and A. Mehl (2009), "Do China and Oil Exporters Influence Major Currency Configurations?” Journal of Comparative Economics, 37, pp. 335-358.

Giavazzi, F., A. Giovannini, D. Begg and L. Katseli (1986), "The EMS and the Dollar,” Economic Policy, Vol. 1, No. 2, pp. 455-485.

Giavazzi, F. and A. Giovannini (1987), "Models of the EMS: Is Europe a Greater Deutschmark Area?” in R. C. Bryant and R. Portes, eds, Global Macroeconomics, New York: St. Martin’s Press, 1987

Giavazzi, F. and M. Pagano (1998), “The Advantage of Tying One’s Hands: EMS Discipline and Central Bank Credibility,” European Economic Review, May 1988, 32, pp. 1055-1082.

Gourinchas, P.-O. and H. Rey (2007a), "From World Banker to World Venture Capitalist: US External Adjustment and the Exorbitant Privilege," in Clarida, R.(ed.) G-7 Current Account Imbalances: Sustainability and Adjustment, pp. 1155, Chicago, University of Chicago Press.

Gourinchas, P.-O. and H. Rey (2007b), “International Financial Adjustment,” Journal of Political Economy, pp. 665-703.

Gros, D. and N. Thygesen (1988), "Le SME: performances et perspectives," Observations et diagnostiques économiques, January 1988, 24, pp. 55-80.

Hummels, D., J. Ishii, and K. Yi (2001), "The Nature and Growth of Vertical Specialization in World Trade,” Journal of International Economics, 54, pp. 7596. 
Ito, T (2010), “China as Number One: How About the Renminbi?” Asian Economic Policy Review Issue 5(2), pp. 249-276.

Kenen, P. (2011), "Beyond the Dollar", paper presented at the AEA Allied Social Science Association Meetings, Denver, Colorado.

Koopman, R. , Z. Wang, and S.-J. Wei (2008), "How Much Chinese Exports Is Really Made in China - Assessing Foreign and Domestic Value-added in Gross Exports.” NBER Working Paper, No. 14109.

Ma, G. and R. McCauley (2010), “The Evolving Renminbi Regime and Implications for Asian Currency Stability,” BIS working paper, No. 312, September 2010.

Marsh, D. (2009), The Euro - The Politics of the New Global Currency, Yale University Press: New Haven and London.

McKinnon, R. \& G. Schnabl (2004), "The East Asian Dollar Standard, Fear of Floating and Original Sin,” Review of Development Economics, Vol. 8(3), pp. 331360.

Melvin, M. and J. Prins (2010), "The Equity Hedging Channel of Exchange rate Adjustment,” Global Markets Strategies Group, Blackrock, mimeo.

Reade, J. James and Ulrich Volz, (2011), "Leader of the pack? German monetary dominance in Europe prior to EMU”, Economic Modelling 28, pp. 239-250.

Reinhart, C. and K. Rogoff (2004), "The Modern History of Exchange Rate Arrangements: A Reinterpretation,” Quarterly Journal of Economics, Vol. CXIX, 1, pp. 1-48.

Russo, M. and G. Tullio (1988), "Monetary Coordination Within the European Monetary System: Is There a Rule?,” IMF Occasional Paper, 61, 1988.

Sarno, L. and M. Taylor (2001), "Official Intervention in the Foreign Exchange Market: is it Effective and, if so, How Does it Work?” Journal of Economic Literature, 39, pp. 839-868.

Von Hagen, J. and Fratianni, M. (1990), “German Dominance in the EMS: Evidence from Interest Rates”, Journal of International Money and Finance, 9, pp. 358-375.

Weber, A., R. Baldwin and M. Obstfeld (1991), "Reputation and Credibility in the European Monetary System,” Economic Policy, Vol. 6, No. 12, pp. 57-102.

Zhou, X. (2009), Reform of the International Monetary System, essay posted on the website of the People’s Bank of China, 9 April 2009. 
Figure 1: US and euro factors
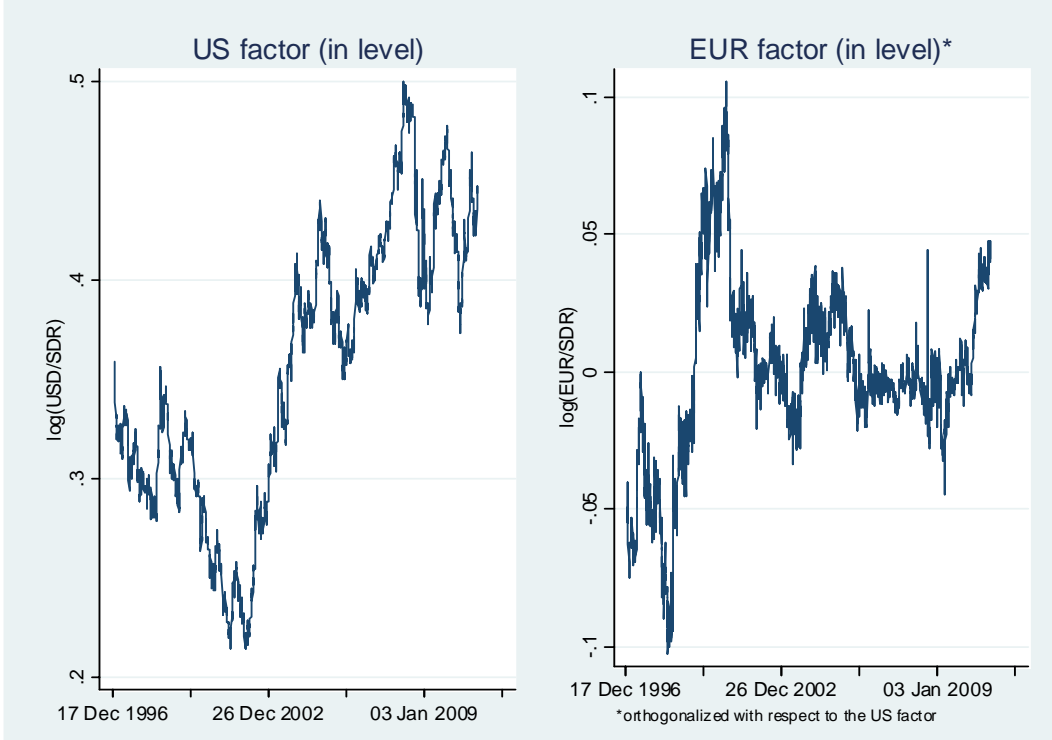

Note: The figures show the US factor (USD/SDR) along with the euro factor (EUR/SDR) used in the unconditional model described in Eq. (1). An upward movement indicates depreciation relative to the SDR basket (euro, US dollar, pound sterling and yen). Our identification condition is that the US factor is considered exogenous, reflecting the US dollar's dominant role in the international monetary system, while the euro factor is orthogonalized with respect to the US dollar factor. Factor levels are shown to facilitate visual interpretation, although we use in the empirical estimation 2-day (non-overlapping) returns to ensure that the variables are stationary.

Figure 2: Regional factors

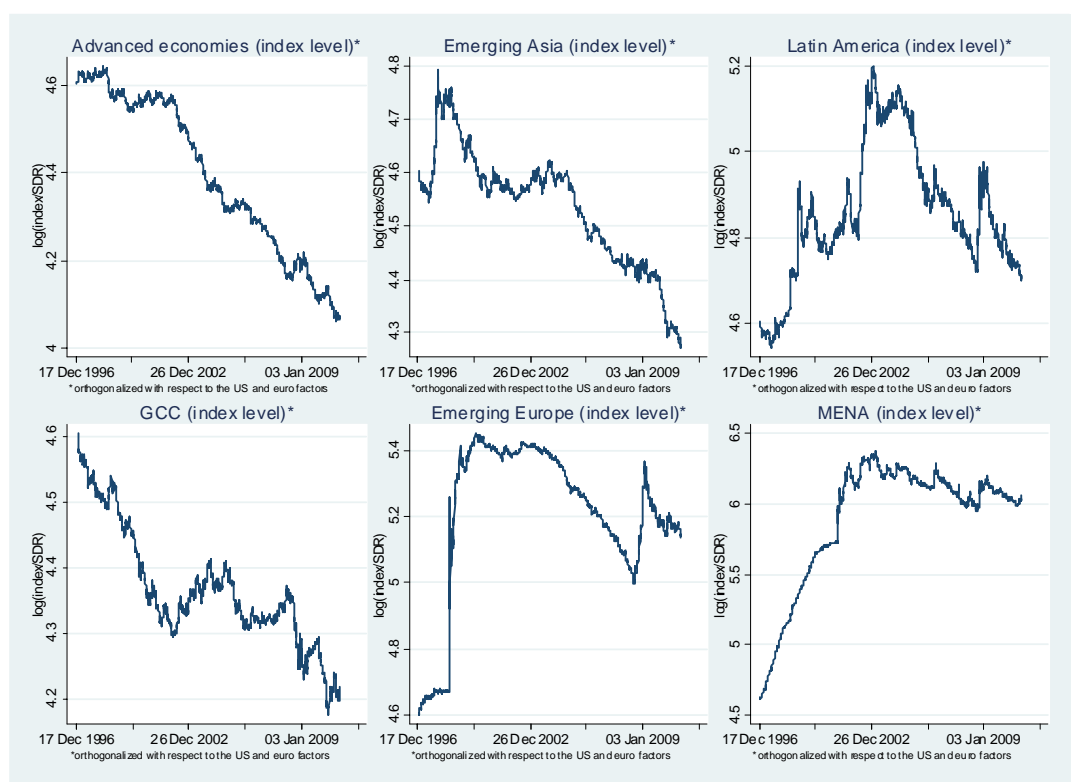

Note: The figures show the regional factor (regional currency index/SDR) corresponding to each of our six regions. An upward movement indicates depreciation relative to the SDR basket. Our identification conditions are that the US factor and the euro factor are considered as exogenous, while the regional factor is orthogonalized with respect to these two factors. Factor levels are shown to facilitate visual interpretation, although we use in the empirical estimation 2-day (non-overlapping) returns to ensure that the variables are stationary. As the regional factor for country $i$ is calculated by excluding country $i$ itself, to make sure that it is not on both sides of Eq. (1), regional factors are country specific (but very highly correlated within regions). The factors shown here are those for Switzerland, Hong Kong, Argentina, Bahrain, Hungary and South Africa. 
Figure 3: RMB/USD exchange rate and official statements by Chinese policymakers on exchange rate and reserve policy

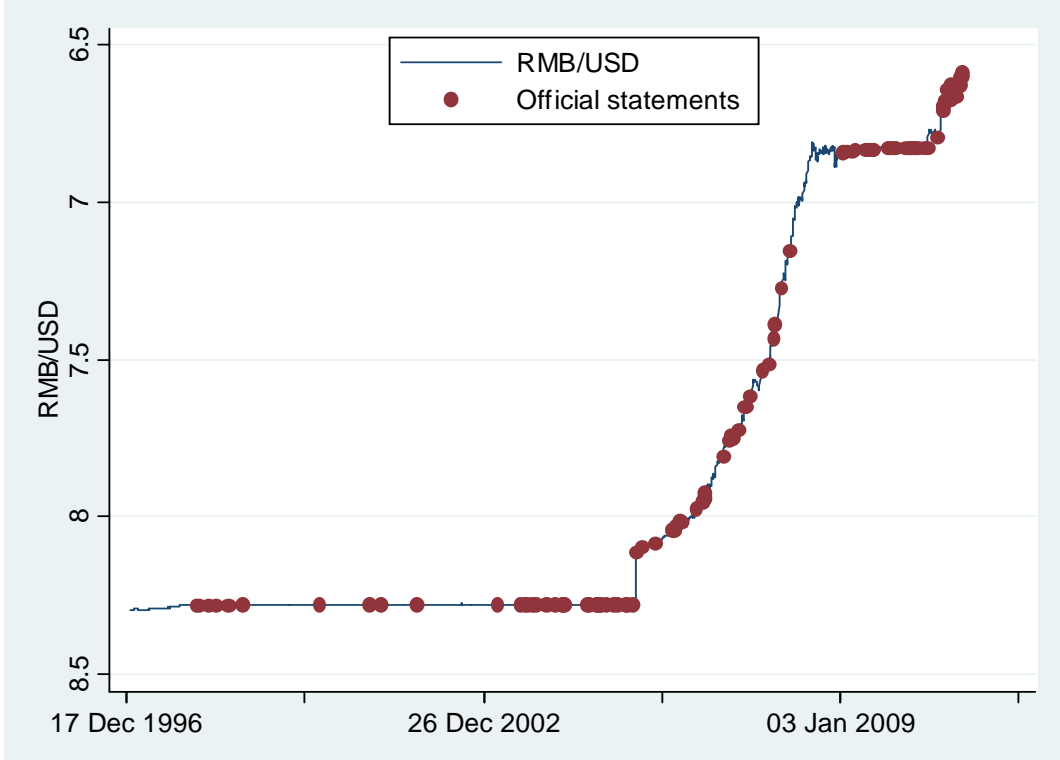

Note: reversed scale for the $y$-axis. Source: authors’ own compilation from Reuters News and Factiva; Bloomberg.

Figure 4: Distribution of regional factor loadings

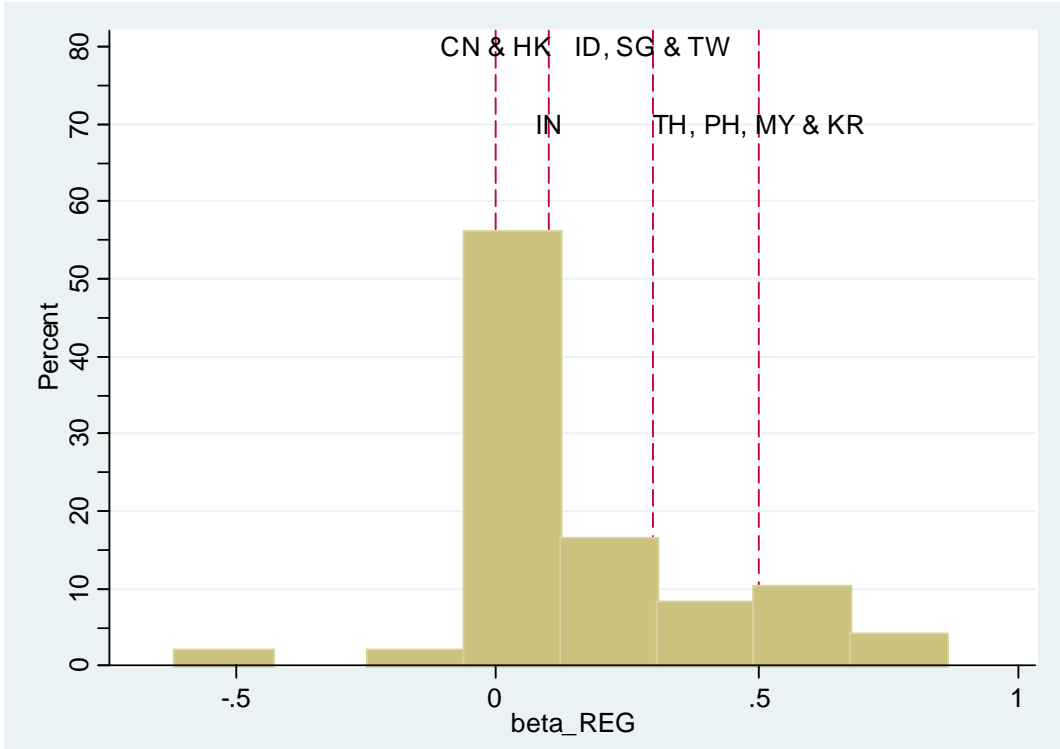

Note: The figure shows the distribution of the regional factor loadings $\beta_{i}^{R E G}$ when estimating Eq. (1) for each of the 48 countries of our sample. The estimates specific to emerging Asian countries are indicated by the red lines (CN: China; HK: Hong Kong; IN: India; ID: Indonesia; SG: Singapore; TW: Taiwan; TH: Thailand; PH: Philippines; MY: Malaysia; KR: Korea). 
Figure 5: Impact of a Chinese official statement on global FX markets (breakdown by currency; SDR as numéraire currency; in \%)

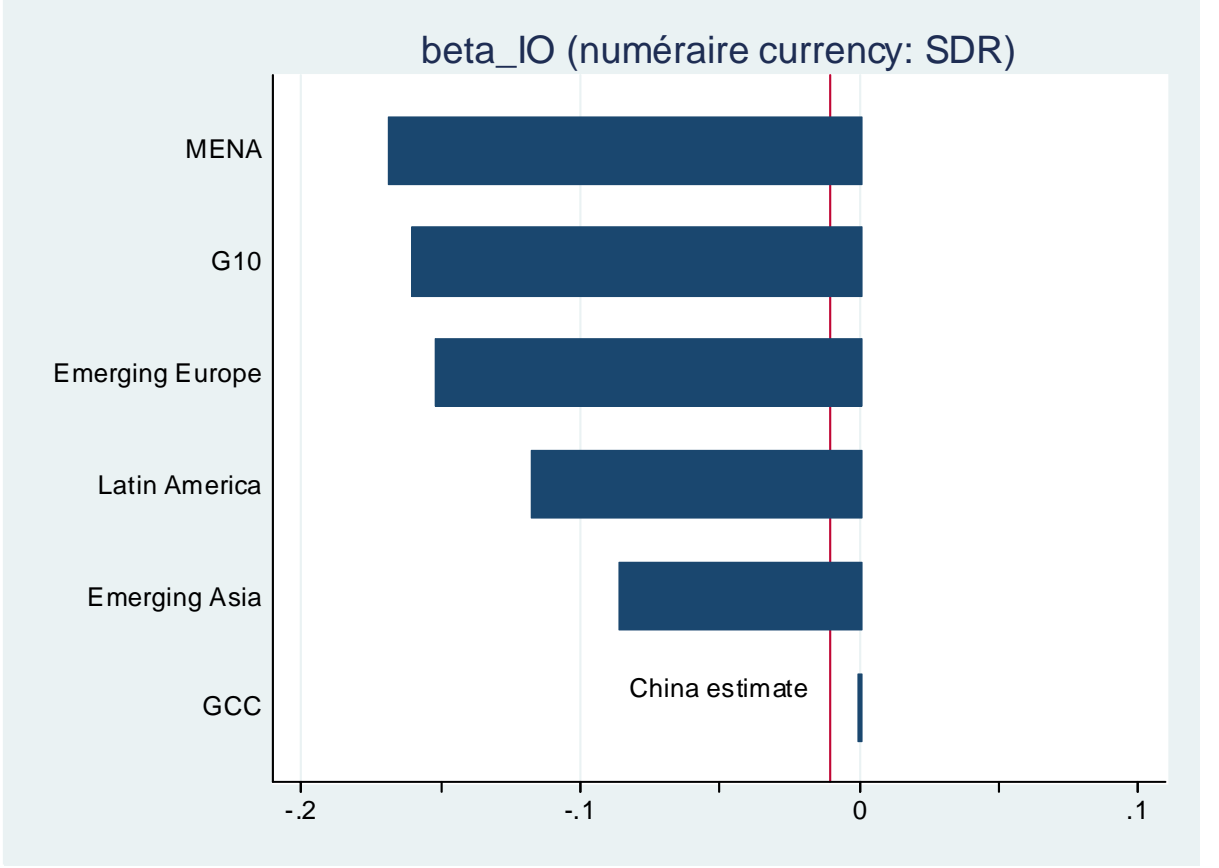

Note: The figure shows the average impact (in \%) as estimated from Eq. (2) of an official statement by Chinese policy-makers on exchange rate/reserve allocation policy on each of our sample's 48 currencies on the day the statement occurs. Estimates shown are equally-weighted averages for all currencies within a particular region or group. The SDR basket is used as numéraire. A negative entry indicates an appreciation of the respective currency vis-à-vis the SDR. 
Table 1: List of the countries included in the sample

\begin{tabular}{|c|c|c|c|c|c|}
\hline $\begin{array}{l}\text { Advanced } \\
\text { economies }\end{array}$ & Emerging Asia & Latin America & $\begin{array}{l}\text { Gulf Co-operation } \\
\text { Council }\end{array}$ & Emerging Europe & $\begin{array}{l}\text { Middle-East and } \\
\text { Northern Africa }\end{array}$ \\
\hline Australia & China & Argentina & Bahrain & Bulgaria & Israel \\
\hline Canada & Hong Kong & Brazil & Oman & Czech Republic & Lebanon \\
\hline Euro* & India & Chile & Qatar & Estonia & Southafrica \\
\hline Japan & Indonesia & Colombia & Saudi Arabia & Hungary & Turkey \\
\hline New Zealand & Korea & Mexico & United Arab Emirates & Latvia & \\
\hline Norway & Malaysia & Peru & & Lithuania & \\
\hline Sweden & Philippines & Venezuela & & Poland & \\
\hline Switzerland & Singapore & & & Romania & \\
\hline United Kingdom & Taiwan & & & Russia & \\
\hline United States* & $\begin{array}{l}\text { Thailand } \\
\text { Vetnam }\end{array}$ & & & Ukraine & \\
\hline $\begin{array}{l}\text { Denmark } \\
\text { Iceland }\end{array}$ & & & & & \\
\hline
\end{tabular}

Note: The table reports the 48 countries included in our sample broken down by country group/region. The euro and the US dollar are reported pro memoria since they enter as explanatory variables in the models of Eq. (1) and (2).

Table 2: Pair-wise correlations across the three factors (prior to orthogonalization)

\begin{tabular}{lrrrr}
\hline \hline & US factor & $\begin{array}{r}\text { Euro } \\
\text { factor }\end{array}$ & $\begin{array}{r}\text { Regional } \\
\text { factor }\end{array}$ \\
\cline { 2 - 3 } US factor & 1 & & \\
Euro factor & $-0.1416^{*}$ & 1 & \\
Regional factor (all countries) & $0.1380^{*}$ & $0.1543^{*}$ & 1 \\
Regional factor (by region) & & & \\
- only advanced economies & $-0.1385^{*}$ & $0.7685^{*}$ & 1 \\
- only emerging Asia & $0.5186^{*}$ & $-0.0239^{*}$ & 1 \\
- only Latin America & $0.2517^{*}$ & $0.0367^{*}$ & 1 \\
- only GCC & $0.7357^{*}$ & $-0.0703^{*}$ & 1 \\
- only emerging Europe & $0.0174^{*}$ & $0.1254^{*}$ & 1 \\
- only MENA & $0.0462^{*}$ & $0.1472^{*}$ & 1 \\
\hline \hline
\end{tabular}

Note: $(*)$ indicates that the correlation coefficient is significant at the $5 \%$ level of confidence.

The correlations are calculated using 2-day (non-overlapping) exchange rate returns. 
Table 3: Global exchange rate factor model - Full sample estimates

\begin{tabular}{|c|c|c|c|c|c|c|}
\hline & \multicolumn{3}{|c|}{ Pooled OLS } & \multicolumn{3}{|c|}{ Fixed effects } \\
\hline & (1) & (2) & (3) & (4) & (5) & (6) \\
\hline US factor & $\begin{array}{r}0.391^{* * * *} \\
(0.077)\end{array}$ & $\begin{array}{r}0.389 * * * \\
(0.072)\end{array}$ & $\begin{array}{r}0.399 * * * \\
(0.072)\end{array}$ & $\begin{array}{r}0.391 * * * \\
(0.077)\end{array}$ & $\begin{array}{r}0.389 * * * \\
(0.072)\end{array}$ & $\begin{array}{r}0.399 * * * \\
(0.072)\end{array}$ \\
\hline Euro factor & $\begin{array}{r}0.171^{* * *} \\
(0.037)\end{array}$ & $\begin{array}{r}0.170 * * * \\
(0.036)\end{array}$ & $\begin{array}{r}0.161^{* * * *} \\
(0.035)\end{array}$ & $\begin{array}{r}0.171^{* * *} \\
(0.037)\end{array}$ & $\begin{array}{r}0.170 * * * \\
(0.036)\end{array}$ & $\begin{array}{r}0.161^{* * * *} \\
(0.035)\end{array}$ \\
\hline Regional factor & & $\begin{array}{r}0.153^{* * * *} \\
(0.023)\end{array}$ & $\begin{array}{r}0.139 * * * \\
(0.023)\end{array}$ & & $\begin{array}{r}0.153 * * * \\
(0.023)\end{array}$ & $\begin{array}{r}0.139 * * * \\
(0.023)\end{array}$ \\
\hline Oil prices & & & $\begin{array}{r}-0.014^{* * *} \\
(0.002)\end{array}$ & & & $\begin{array}{r}-0.014 * * * \\
(0.002)\end{array}$ \\
\hline Liquidity risk & & & $\begin{array}{c}0.110 * * \\
(0.044)\end{array}$ & & & $\begin{array}{r}0.111^{* *} \\
(0.044)\end{array}$ \\
\hline Risk aversion & & & $\begin{array}{r}0.037 * * * \\
(0.007)\end{array}$ & & & $\begin{array}{r}0.037 * * * \\
(0.007)\end{array}$ \\
\hline Constant & $\begin{array}{r}0.009 * * \\
(0.004)\end{array}$ & $\begin{array}{r}0.009 * * \\
(0.004)\end{array}$ & $\begin{array}{r}0.010 * * \\
(0.004)\end{array}$ & $\begin{array}{c}0.009 * * \\
(0.004)\end{array}$ & $\begin{array}{c}0.009 * * \\
(0.004)\end{array}$ & $\begin{array}{r}0.010^{* * *} \\
(0.004)\end{array}$ \\
\hline Observations & 85,823 & 85,819 & 85,819 & 85,823 & 85,819 & 85,819 \\
\hline $\begin{array}{l}\text { Adjusted } R^{2} \\
\rho\end{array}$ & 0.0679 & 0.0915 & 0.108 & $\begin{array}{r}0.0679 \\
0.000519 \\
\end{array}$ & $\begin{array}{r}0.0916 \\
0.000567 \\
\end{array}$ & $\begin{array}{r}0.108 \\
0.000582 \\
\end{array}$ \\
\hline
\end{tabular}

Note: Pooled OLS and fixed effect estimates of Eq. (1) for the full sample. Robust standard errors are reported in parentheses. $(* * *),(* *)$ and $(*)$ denote statistical significance at the $1 \%, 5 \%$ and $10 \%$ level of confidence, respectively.

Table 4: Global exchange rate factor model - Full sample estimates (by time period)

\begin{tabular}{lrr}
\hline \hline & \multicolumn{1}{r}{ Before 2005 } & \multicolumn{1}{c}{ After 2005 } \\
& \multicolumn{1}{c}{$(1)$} & \multicolumn{1}{c}{$(2)$} \\
\cline { 2 - 3 } US factor & & \\
& $0.537^{* * *}$ & $0.301^{* * *}$ \\
Euro factor & $(0.068)$ & $(0.073)$ \\
& $0.111^{* * *}$ & $0.194^{* * *}$ \\
Regional factor & $(0.034)$ & $(0.040)$ \\
& $0.074^{* * *}$ & $0.322^{* * *}$ \\
Oil prices & $(0.019)$ & $(0.055)$ \\
& $-0.005^{* * *}$ & $-0.018^{* * *}$ \\
Liquidity risk & $(0.001)$ & $(0.004)$ \\
& 0.077 & $0.081^{*}$ \\
Risk aversion & $(0.054)$ & $(0.048)$ \\
& $0.017^{* * *}$ & $0.037^{* * *}$ \\
Constant & $(0.005)$ & $(0.008)$ \\
& $0.018^{* * *}$ & 0.004 \\
& $(0.006)$ & $(0.004)$ \\
Observations & & \\
Adjusted $R^{2}$ & 48,644 & 37,175 \\
\hline \hline
\end{tabular}

Note: Pooled OLS estimates of Eq. (1) for the full sample and for two sub-periods: (i) before the start of China's exchange rate reform in 2005 and (ii) after the start of the reform. Robust standard errors are reported in parentheses. $\left({ }^{* *}\right),\left({ }^{* *}\right)$ and $(*)$ denote statistical significance at the $1 \%, 5 \%$ and $10 \%$ level of confidence, respectively. 
Table 5: Global exchange rate factor model - Full sample estimates (by country group/region)

\begin{tabular}{|c|c|c|c|c|c|c|c|}
\hline & $\begin{array}{c}\text { Advanced } \\
\text { economies } \\
(1)\end{array}$ & $\begin{array}{c}\text { Emerging } \\
\text { economies } \\
(2) \\
\end{array}$ & $\begin{array}{c}\text { Emerging } \\
\text { Asia } \\
(3) \\
\end{array}$ & $\begin{array}{c}\text { Latin } \\
\text { America } \\
(4)\end{array}$ & (5) & $\begin{array}{c}\text { Emerging } \\
\text { Europe } \\
(6) \\
\end{array}$ & $M E N A$ \\
\hline US factor & $\begin{array}{r}-0.018 \\
(0.137)\end{array}$ & $\begin{array}{r}0.523^{* * *} \\
(0.077)\end{array}$ & $\begin{array}{r}0.656^{* * *} \\
(0.078)\end{array}$ & $\begin{array}{r}0.779 * * * \\
(0.076)\end{array}$ & $\begin{array}{r}0.999 * * * \\
(0.001)\end{array}$ & $\begin{array}{r}-0.070 \\
(0.142)\end{array}$ & $\begin{array}{c}0.493 * \\
(0.203)\end{array}$ \\
\hline Euro factor & $\begin{array}{c}0.244 * \\
(0.114)\end{array}$ & $\begin{array}{r}0.122^{* * *} \\
(0.030)\end{array}$ & $\begin{array}{r}0.085^{* * *} \\
(0.020)\end{array}$ & $\begin{array}{r}0.087 * * \\
(0.028)\end{array}$ & $\begin{array}{r}-0.000 \\
(0.001)\end{array}$ & $\begin{array}{r}0.284 * * * \\
(0.081)\end{array}$ & $\begin{array}{r}0.145 \\
(0.092)\end{array}$ \\
\hline Regional factor & $\begin{array}{r}0.135 \\
(0.228)\end{array}$ & $\begin{array}{r}0.113^{* * *} \\
(0.016)\end{array}$ & $\begin{array}{r}0.216 * * \\
(0.077)\end{array}$ & $\begin{array}{r}0.165 * * \\
(0.053)\end{array}$ & $\begin{array}{r}-0.000 \\
(0.002)\end{array}$ & $\begin{array}{r}0.045^{* * *} \\
(0.008)\end{array}$ & $\begin{array}{c}0.073 * \\
(0.029)\end{array}$ \\
\hline Oil prices & $\begin{array}{r}-0.029^{* *} \\
(0.009)\end{array}$ & $\begin{array}{r}-0.011^{* * *} \\
(0.002)\end{array}$ & $\begin{array}{r}-0.005^{* * *} \\
(0.001)\end{array}$ & $\begin{array}{c}-0.011^{*} \\
(0.005)\end{array}$ & $\begin{array}{r}0.000 \\
(0.000)\end{array}$ & $\begin{array}{r}-0.021^{* * *} \\
(0.004)\end{array}$ & $\begin{array}{r}-0.011 \\
(0.007)\end{array}$ \\
\hline Liquidity risk & $\begin{array}{r}0.103 \\
(0.182)\end{array}$ & $\begin{array}{r}0.102 * * \\
(0.043)\end{array}$ & $\begin{array}{c}0.147^{* *} \\
(0.060)\end{array}$ & $\begin{array}{c}0.210 * \\
(0.106)\end{array}$ & $\begin{array}{c}-0.003^{*} \\
(0.001)\end{array}$ & $\begin{array}{r}-0.035 \\
(0.074)\end{array}$ & $\begin{array}{r}0.093 \\
(0.267)\end{array}$ \\
\hline Risk aversion & $\begin{array}{r}0.037 \\
(0.023)\end{array}$ & $\begin{array}{r}0.039 * * * \\
(0.007)\end{array}$ & $\begin{array}{r}0.029 * * * \\
(0.009)\end{array}$ & $\begin{array}{c}0.054^{* *} \\
(0.018)\end{array}$ & $\begin{array}{r}-0.000 \\
(0.000)\end{array}$ & $\begin{array}{r}0.050^{* * *} \\
(0.011)\end{array}$ & $\begin{array}{r}0.068 \\
(0.034)\end{array}$ \\
\hline Constant & $\begin{array}{r}-0.000 \\
(0.006)\end{array}$ & $\begin{array}{r}0.011^{* *} \\
(0.004)\end{array}$ & $\begin{array}{r}0.013^{* *} \\
(0.005)\end{array}$ & $\begin{array}{c}0.014 * \\
(0.006)\end{array}$ & $\begin{array}{r}0.000 \\
(0.000)\end{array}$ & $\begin{array}{r}0.011 \\
(0.010)\end{array}$ & $\begin{array}{r}0.027 \\
(0.029)\end{array}$ \\
\hline $\begin{array}{l}\text { Observations } \\
\text { Adiusted } R^{2}\end{array}$ & 14,655 & 67,510 & 20,022 & 12,760 & 9,164 & 18,258 & 7,306 \\
\hline Adjusted $R^{2}$ & 0.0802 & 0.141 & 0.238 & 0.235 & 0.994 & 0.0976 & 0.0960 \\
\hline
\end{tabular}

Note: Pooled OLS estimates of Eq. (1) for each of the sample's country groups or regions. Robust standard errors are reported in parentheses. $\left({ }^{* *}\right),\left({ }^{* *}\right)$ and $(*)$ denote statistical significance at the $1 \%, 5 \%$ and $10 \%$ level of confidence, respectively. GCC $=$ Gulf Co-operation Council; MENA = Middle-East and Northern Africa.

\section{Table 6: Global exchange rate factor model - Estimates for emerging Asia (by time period)}

\begin{tabular}{lrr}
\hline \hline & $\begin{array}{r}\text { Before 2005 } \\
(1)\end{array}$ & $\begin{array}{r}\text { After 2005 } \\
(2)\end{array}$ \\
\cline { 2 - 3 } US factor & $0.736^{* * *}$ & $0.598^{* * *}$ \\
Euro factor & $(0.072)$ & $(0.087)$ \\
& $0.042^{*}$ & $0.146^{* * *}$ \\
Regional factor & $(0.019)$ & $(0.036)$ \\
& $0.186^{* *}$ & $0.251^{* * *}$ \\
Oil prices & $(0.077)$ & $(0.077)$ \\
& -0.003 & $-0.003^{*}$ \\
Liquidity risk & $(0.002)$ & $(0.002)$ \\
Risk aversion & $0.263^{*}$ & 0.065 \\
& $(0.138)$ & $(0.045)$ \\
Constant & $0.014^{* *}$ & $0.034^{* *}$ \\
& $(0.005)$ & $(0.011)$ \\
& $0.024^{* *}$ & -0.002 \\
Observations & $(0.008)$ & $(0.007)$ \\
Adjusted $R^{2}$ & & \\
\hline \hline
\end{tabular}

Note: Pooled OLS estimates of Eq. (1) restricted to emerging Asia and for two sub-periods: (i) before the start of China's exchange rate reform in 2005 and (ii) after the start of the reform. Robust standard errors are reported in parentheses. $\left({ }^{* *}\right),\left({ }^{* *}\right)$ and $(*)$ denote statistical significance at the $1 \%, 5 \%$ and $10 \%$ level of confidence, respectively. 
Table 7: Global exchange rate factor model - Estimates for emerging Asia (RMB used as regional factor)

\begin{tabular}{|c|c|c|c|c|c|c|}
\hline & Full sample & Before 2005 & After 2005 & $\begin{array}{c}\text { Pre-crisis } \\
\text { (2005/7) }\end{array}$ & $\begin{array}{c}\text { Financial } \\
\text { turmoil } \\
(2007 / 8)\end{array}$ & $\begin{array}{c}\text { Post-crisis } \\
\text { (since 2009) }\end{array}$ \\
\hline & (1) & $(2)$ & (3) & $(4)$ & (5) & (6) \\
\hline US factor & $\begin{array}{r}0.695^{* * *} \\
(0.059)\end{array}$ & $\begin{array}{r}0.771^{* * *} \\
(0.051)\end{array}$ & $\begin{array}{r}0.645^{* * *} \\
(0.069)\end{array}$ & $\begin{array}{r}0.632 * * * \\
(0.086)\end{array}$ & $\begin{array}{r}0.640 * * * \\
(0.062)\end{array}$ & $\begin{array}{r}0.687^{* * *} \\
(0.063)\end{array}$ \\
\hline Euro factor & $\begin{array}{r}0.047^{* *} \\
(0.016)\end{array}$ & $\begin{array}{r}0.001 \\
(0.011)\end{array}$ & $\begin{array}{r}0.120^{* * *} \\
(0.034)\end{array}$ & $\begin{array}{r}0.053 \\
(0.029)\end{array}$ & $\begin{array}{r}0.172^{* * *} \\
(0.053)\end{array}$ & $\begin{array}{r}0.150 * * \\
(0.052)\end{array}$ \\
\hline RMB factor & $\begin{array}{r}0.031 \\
(0.036)\end{array}$ & $\begin{array}{r}0.002 \\
(0.028)\end{array}$ & $\begin{array}{r}0.063 \\
(0.052)\end{array}$ & $\begin{array}{r}0.017 \\
(0.042)\end{array}$ & $\begin{array}{r}0.029 \\
(0.089)\end{array}$ & $\begin{array}{r}0.147^{* *} \\
(0.053)\end{array}$ \\
\hline Oil prices & $\begin{array}{r}-0.006^{* * *} \\
(0.001)\end{array}$ & $\begin{array}{c}-0.004 * \\
(0.002)\end{array}$ & $\begin{array}{c}-0.003 * \\
(0.002)\end{array}$ & $\begin{array}{r}0.001 \\
(0.002)\end{array}$ & $\begin{array}{r}0.003 \\
(0.002)\end{array}$ & $\begin{array}{r}-0.010^{* *} \\
(0.003)\end{array}$ \\
\hline Liquidity risk & $\begin{array}{r}0.154^{* *} \\
(0.060)\end{array}$ & $\begin{array}{c}0.300 * \\
(0.140)\end{array}$ & $\begin{array}{r}0.039 \\
(0.047)\end{array}$ & $\begin{array}{r}0.303 \\
(0.184)\end{array}$ & $\begin{array}{r}0.037 \\
(0.050)\end{array}$ & $\begin{array}{c}1.282 * \\
(0.597)\end{array}$ \\
\hline Risk aversion & $\begin{array}{r}0.039 * * * \\
(0.009)\end{array}$ & $\begin{array}{r}0.020^{* * *} \\
(0.005)\end{array}$ & $\begin{array}{r}0.047^{* * *} \\
(0.012)\end{array}$ & $\begin{array}{r}0.019 * * \\
(0.007)\end{array}$ & $\begin{array}{r}0.042^{* * *} \\
(0.012)\end{array}$ & $\begin{array}{r}0.058^{* * *} \\
(0.016)\end{array}$ \\
\hline Constant & $\begin{array}{r}0.011^{* *} \\
(0.004)\end{array}$ & $\begin{array}{r}0.026 * * * \\
(0.008)\end{array}$ & $\begin{array}{r}-0.008 \\
(0.007)\end{array}$ & $\begin{array}{r}-0.021 * * \\
(0.008)\end{array}$ & $\begin{array}{r}0.026 \\
(0.019)\end{array}$ & $\begin{array}{l}-0.022^{*} \\
(0.010)\end{array}$ \\
\hline Observations & 18,188 & 10,267 & 7,921 & 2,600 & 2,606 & 2,715 \\
\hline Adjusted $R^{2}$ & 0.200 & 0.186 & 0.244 & 0.279 & 0.229 & 0.257 \\
\hline
\end{tabular}

Note: Pooled OLS estimates of Eq. (1) restricted to emerging Asia and for various sub-periods: (i) before the start of China's exchange rate reform in 2005; (ii) after the start of the reform; (iii) before the eruption of the global financial crisis (2005/7); (iv) during the intensification of the global financial turmoil (2007/08); (v) since the onset of the recovery in emerging Asia (post-2009). The RMB/SDR (orthogonal with respect to both the US and euro factors) is taken here as regional factor. China is excluded from the estimation so as not to have it on both sides of the regression. Robust standard errors are reported in parentheses. $\left({ }^{* *}\right),\left({ }^{* *}\right)$ and $(*)$ denote statistical significance at the $1 \%, 5 \%$ and $10 \%$ level of confidence, respectively.

Table 8: Granger causality test results

\begin{tabular}{|c|c|c|c|c|}
\hline \multirow{3}{*}{\multicolumn{2}{|c|}{ (1) }} & \multicolumn{3}{|c|}{ Lag order of the VAR model } \\
\hline & & 1 & 2 & 3 \\
\hline & & \multicolumn{3}{|c|}{$H^{\prime \prime}$ : RMB does not cause Asia's regional factor } \\
\hline All sample & & 0.001 & 0.026 & 0.058 \\
\hline Pre-2005 & & 0.014 & 0.205 & 0.301 \\
\hline Post-2005 & & 0.004 & 0.000 & 0.000 \\
\hline & Pre-crisis $(2005 / 06)$ & 0.188 & 0.067 & 0.095 \\
\hline & Crisis (2007/08) & 0.315 & 0.042 & 0.103 \\
\hline & Post-crisis (post-2009) & 0.008 & 0.001 & 0.004 \\
\hline \multicolumn{5}{|c|}{$H^{\prime \prime \prime}{ }_{0}$ : Asia's regional factor does not cause RMB } \\
\hline All sample & & 0.000 & 0.000 & 0.000 \\
\hline Pre-2005 & & 0.000 & 0.000 & 0.000 \\
\hline Post-2005 & & 0.015 & 0.026 & 0.058 \\
\hline & Pre-crisis $(2005 / 06)$ & 0.000 & 0.000 & 0.000 \\
\hline & Crisis $(2007 / 08)$ & 0.457 & 0.397 & 0.538 \\
\hline & Post-crisis (post-2009) & 0.000 & 0.001 & 0.001 \\
\hline
\end{tabular}

Note: Granger causality test results based on a bi-variate VAR estimated for emerging Asia and including the $\mathrm{RMB} / \mathrm{SDR}$ and the regional factor (excluding China), with up to 3 lags. The table shows the $p$-value of the corresponding $F$-tests for various sub-periods. 
Table 9: Conditional analysis - Full sample estimates

\begin{tabular}{lrrrrrr}
\hline \hline & \multicolumn{3}{c}{ Pooled OLS } & \multicolumn{3}{c}{ Fixed effects } \\
& \multicolumn{1}{c}{$(1)$} & \multicolumn{1}{c}{$(2)$} & \multicolumn{1}{c}{$(4)$} & \multicolumn{1}{c}{$(5)$} & \multicolumn{1}{c}{$(6)$} \\
\cline { 2 - 7 } Chinese statements & $-0.105^{* * *}$ & $-0.105^{* * *}$ & $-0.104^{* * *}$ & $-0.105^{* * *}$ & $-0.105^{* * *}$ & $-0.104^{* * *}$ \\
& $(0.015)$ & $(0.015)$ & $(0.015)$ & $(0.015)$ & $(0.015)$ & $(0.015)$ \\
US factor & $0.395^{* * *}$ & $0.393^{* * *}$ & $0.403^{* * *}$ & $0.395^{* * *}$ & $0.393^{* * *}$ & $0.403^{* * *}$ \\
& $(0.077)$ & $(0.072)$ & $(0.071)$ & $(0.077)$ & $(0.072)$ & $(0.071)$ \\
Euro factor & $0.169^{* * *}$ & $0.169^{* * *}$ & $0.159^{* * *}$ & $0.169^{* * *}$ & $0.169^{* * *}$ & $0.159^{* * *}$ \\
& $(0.037)$ & $(0.035)$ & $(0.035)$ & $(0.037)$ & $(0.035)$ & $(0.035)$ \\
Regional factor & & $0.152^{* * *}$ & $0.139^{* * *}$ & & $0.152^{* * *}$ & $0.139^{* * *}$ \\
& & $(0.023)$ & $(0.023)$ & & $(0.023)$ & $(0.023)$ \\
Oil prices & & & $-0.014^{* * *}$ & & & $-0.014^{* * *}$ \\
& & & $(0.002)$ & & & $(0.002)$ \\
Liquidity risk & & & $0.114^{* *}$ & & & $0.114^{* *}$ \\
& & & $(0.044)$ & & & $(0.044)$ \\
Risk aversion & & & $0.037^{* * *}$ & & & $0.037^{* * *}$ \\
Constant & & & $(0.007)$ & & & $(0.007)$ \\
& $0.012^{* * *}$ & $0.012^{* * *}$ & $0.013^{* * *}$ & $0.012^{* * *}$ & $0.012^{* * *}$ & $0.013^{* * *}$ \\
& $(0.004)$ & $(0.004)$ & $(0.004)$ & $(0.004)$ & $(0.004)$ & $(0.004)$ \\
Observations & & & & & & \\
Adjusted $R^{2}$ & 85,823 & 85,819 & 85,819 & 85,823 & 85,819 & 85,819 \\
$\rho$ & 0.0684 & 0.0918 & 0.109 & 0.0685 & 0.0919 & 0.109 \\
\hline \hline
\end{tabular}

Note: Pooled OLS and fixed effect estimates of Eq. (2) for the full sample. Robust standard errors are reported in parentheses. $\left({ }^{* *}\right),\left({ }^{* *}\right)$ and $(*)$ denote statistical significance at the $1 \%, 5 \%$ and $10 \%$ level of confidence, respectively.

Table 10: Conditional analysis - Full sample estimates (by time period)

\begin{tabular}{lrr}
\hline \hline & $\begin{array}{r}\text { Before 2005 } \\
(1)\end{array}$ & \multicolumn{1}{c}{ After 2005 } \\
\cline { 2 - 3 } Chinese statements & $-0.082^{* * *}$ & $-0.106^{* * *}$ \\
& $(0.018)$ & $(0.018)$ \\
US factor & $0.539^{* * *}$ & $0.305^{* * *}$ \\
& $(0.068)$ & $(0.073)$ \\
Euro factor & $0.110^{* * *}$ & $0.192^{* * *}$ \\
& $(0.034)$ & $(0.040)$ \\
Regional factor & $0.073^{* * *}$ & $0.321^{* * *}$ \\
& $(0.019)$ & $(0.055)$ \\
Oil prices & $-0.005^{* * *}$ & $-0.018^{* * *}$ \\
& $(0.001)$ & $(0.004)$ \\
Liquidity risk & 0.076 & $0.084^{*}$ \\
Risk aversion & $(0.054)$ & $(0.048)$ \\
Constant & $0.017^{* * *}$ & $0.037^{* * *}$ \\
& $(0.005)$ & $(0.008)$ \\
& $0.019^{* * *}$ & $0.008^{* *}$ \\
Observations & $(0.006)$ & $(0.004)$ \\
Adjusted $R^{2}$ & & \\
\hline \hline
\end{tabular}

Note: Pooled OLS estimates of Eq. (2) for the full sample and for two sub-periods: (i) before the start of China's exchange rate reform in 2005 and (ii) after the start of the reform. Robust standard errors are reported in parentheses. $\left({ }^{* *}\right),\left({ }^{* *}\right)$ and $(*)$ denote statistical significance at the $1 \%, 5 \%$ and $10 \%$ level of confidence, respectively. 
Table 11: Conditional analysis - Full sample estimates (by country group/region)

\begin{tabular}{lrrrrrrr}
\hline \hline & $\begin{array}{c}\text { Advanced } \\
\text { economies }\end{array}$ & $\begin{array}{r}\text { Emerging } \\
\text { economies }\end{array}$ & $\begin{array}{c}\text { Emerging } \\
\text { Asia }\end{array}$ & $\begin{array}{c}\text { Latin } \\
\text { America }\end{array}$ & GCC & $\begin{array}{c}\text { Emerging } \\
\text { Europe }\end{array}$ & MENA \\
& \multicolumn{1}{c}{$(1)$} & \multicolumn{1}{c}{$(3)$} & \multicolumn{1}{c}{$(4)$} & \multicolumn{1}{c}{$(5)$} & \multicolumn{1}{c}{$(6)$} & \multicolumn{1}{c}{$(7)$} \\
\cline { 2 - 8 } Chinese statements & $-0.144^{* *}$ & $-0.094^{* * *}$ & $-0.084^{* * *}$ & $-0.111^{* *}$ & 0.000 & $-0.151^{* * *}$ & -0.163 \\
& $(0.048)$ & $(0.016)$ & $(0.025)$ & $(0.038)$ & $(0.001)$ & $(0.028)$ & $(0.071)$ \\
US factor & -0.013 & $0.526^{* * *}$ & $0.660^{* * *}$ & $0.784^{* * *}$ & $0.999^{* * *}$ & -0.066 & $0.499^{*}$ \\
& $(0.138)$ & $(0.077)$ & $(0.077)$ & $(0.076)$ & $(0.001)$ & $(0.141)$ & $(0.201)$ \\
Euro factor & $0.242^{*}$ & $0.121^{* * *}$ & $0.083^{* * *}$ & $0.085^{* *}$ & -0.000 & $0.282^{* * *}$ & 0.142 \\
& $(0.114)$ & $(0.030)$ & $(0.020)$ & $(0.028)$ & $(0.001)$ & $(0.081)$ & $(0.091)$ \\
Regional factor & 0.135 & $0.113^{* * *}$ & $0.215^{* *}$ & $0.164^{* *}$ & -0.000 & $0.043^{* * *}$ & $0.072^{*}$ \\
& $(0.228)$ & $(0.016)$ & $(0.077)$ & $(0.053)$ & $(0.002)$ & $(0.008)$ & $(0.028)$ \\
Oil prices & $-0.029^{* *}$ & $-0.011^{* * *}$ & $-0.005^{* * *}$ & $-0.011^{*}$ & 0.000 & $-0.021^{* * *}$ & -0.011 \\
& $(0.009)$ & $(0.002)$ & $(0.001)$ & $(0.005)$ & $(0.000)$ & $(0.004)$ & $(0.007)$ \\
Liquidity risk & 0.107 & $0.105^{* *}$ & $0.149^{* *}$ & $0.214^{*}$ & $-0.003^{*}$ & -0.031 & 0.100 \\
& $(0.183)$ & $(0.043)$ & $(0.061)$ & $(0.108)$ & $(0.002)$ & $(0.074)$ & $(0.268)$ \\
Risk aversion & 0.037 & $0.039^{* * *}$ & $0.029^{* * *}$ & $0.054^{* *}$ & -0.000 & $0.050^{* * *}$ & 0.069 \\
& $(0.023)$ & $(0.007)$ & $(0.009)$ & $(0.018)$ & $(0.000)$ & $(0.011)$ & $(0.034)$ \\
Constant & 0.004 & $0.014^{* * *}$ & $0.015^{* *}$ & $0.017^{* *}$ & -0.000 & 0.015 & 0.031 \\
& $(0.008)$ & $(0.005)$ & $(0.005)$ & $(0.006)$ & $(0.000)$ & $(0.010)$ & $(0.030)$ \\
& & & & & & & \\
Observations & 14,655 & 67,510 & 20,022 & 12,760 & 9,164 & 18,258 & 7,306 \\
Adjusted $R^{2}$ & 0.0807 & 0.142 & 0.238 & 0.235 & 0.994 & 0.0984 & 0.0969 \\
\hline \hline
\end{tabular}

Note: Pooled OLS estimates of Eq. (2) for each of the sample’s country groups or regions. Robust standard errors are reported in parentheses. $\left({ }^{* * *}\right),\left({ }^{* *}\right)$ and $(*)$ denote statistical significance at the $1 \%, 5 \%$ and $10 \%$ level of confidence, respectively. GCC $=$ Gulf Co-operation Council; MENA = Middle-East and Northern Africa.

Table 12: Conditional analysis - Estimates for emerging Asia (by time period)

\begin{tabular}{lrr}
\hline \hline & $\begin{array}{r}\text { Before 2005 } \\
(1)\end{array}$ & \multicolumn{1}{c}{$\begin{array}{r}\text { After 2005 } \\
(2)\end{array}$} \\
\cline { 2 - 3 } Chinese statements & $-0.039^{*}$ & $-0.092^{* *}$ \\
& $(0.019)$ & $(0.032)$ \\
US factor & $0.738^{* * *}$ & $0.602^{* * *}$ \\
& $(0.072)$ & $(0.086)$ \\
Euro factor & $0.041^{*}$ & $0.144^{* * *}$ \\
& $(0.019)$ & $(0.035)$ \\
Regional factor & $0.185^{* *}$ & $0.249^{* * *}$ \\
& $(0.078)$ & $(0.076)$ \\
Oil prices & -0.003 & $-0.003^{*}$ \\
& $(0.002)$ & $(0.002)$ \\
Liquidity risk & $0.263^{*}$ & 0.068 \\
Risk aversion & $(0.138)$ & $(0.045)$ \\
& $0.014^{* *}$ & $0.034^{* *}$ \\
Constant & $(0.005)$ & $(0.011)$ \\
& $0.025^{* *}$ & 0.002 \\
Observations & $(0.008)$ & $(0.008)$ \\
Adjusted $R^{2}$ & & \\
\hline \hline
\end{tabular}

Note: Pooled OLS estimates of Eq. (2) restricted to emerging Asia and for two sub-periods: (i) before the start of China's exchange rate reform in 2005 and (ii) after the start of the reform. Robust standard errors are reported in parentheses. $\left({ }^{* *}\right),\left({ }^{* *}\right)$ and $(*)$ denote statistical significance at the $1 \%, 5 \%$ and $10 \%$ level of confidence, respectively. 
Table 13: Conditional analysis - Estimates for emerging Asia (US dollar as numéraire currency)

\begin{tabular}{lrr}
\hline \hline & Before 2005 & After 2005 \\
& $(1)$ & $(2)$ \\
\cline { 2 - 3 } Chinese statements & $-0.101^{* *}$ & $-0.189^{* *}$ \\
& $(0.042)$ & $(0.060)$ \\
Euro factor & $0.124^{* *}$ & $0.215^{* * *}$ \\
& $(0.044)$ & $(0.063)$ \\
Regional factor & $0.277^{* *}$ & $0.348^{* *}$ \\
& $(0.115)$ & $(0.148)$ \\
Oil prices & -0.002 & -0.003 \\
& $(0.002)$ & $(0.002)$ \\
Liquidity risk & $0.205^{*}$ & $0.106^{*}$ \\
& $(0.107)$ & $(0.057)$ \\
Risk aversion & $0.010^{*}$ & $0.032^{* *}$ \\
& $(0.004)$ & $(0.011)$ \\
Constant & $0.086^{* *}$ & $0.086^{*}$ \\
& $(0.031)$ & $(0.041)$ \\
Observations & & \\
Adjusted $R^{2}$ & 11,301 & 8,710 \\
\hline \hline
\end{tabular}

Note: Pooled OLS estimates of Eq. (2) restricted to emerging Asia prior to and post-2005 and using the US dollar as numéraire currency (rather than the SDR basket). Robust standard errors are reported in parentheses. $\left({ }^{* * *}\right),\left(^{* *}\right)$ and $(*)$ denote statistical significance at the $1 \%, 5 \%$ and $10 \%$ level of confidence, respectively.

Table 14: Conditional analysis - Estimates for emerging Asia (using forward exchange rates)

\begin{tabular}{lrr}
\hline \hline & $\begin{array}{r}\text { Before 2005 } \\
(1)\end{array}$ & $\begin{array}{c}\text { After 2005 } \\
(2)\end{array}$ \\
\cline { 2 - 3 } Chinese statements & -0.038 & $-0.092^{* *}$ \\
& $(0.028)$ & $(0.030)$ \\
Euro factor & $0.093^{* *}$ & $0.126^{* *}$ \\
Regional factor & $(0.037)$ & $(0.046)$ \\
& $0.214^{*}$ & $0.197^{* *}$ \\
Oil prices & $(0.097)$ & $(0.082)$ \\
& -0.002 & -0.002 \\
Liquidity risk & $(0.002)$ & $(0.002)$ \\
& 0.097 & 0.025 \\
Risk aversion & $(0.117)$ & $(0.050)$ \\
Constant & $0.005^{*}$ & $0.034^{* *}$ \\
& $(0.002)$ & $(0.015)$ \\
& 0.011 & -0.002 \\
Observations & $(0.007)$ & $(0.005)$ \\
Adjusted $R^{2}$ & & \\
\hline \hline
\end{tabular}

Note: Pooled OLS estimates of Eq. (2) restricted to emerging Asia prior to and post-2005 and using bilateral forward exchange rates (vs. the US dollar) rather than spot exchange rates. Robust standard errors are reported in parentheses. $(* * *),\left({ }^{*}\right)$ and $(*)$ denote statistical significance at the $1 \%, 5 \%$ and $10 \%$ level of confidence, respectively. 
Table 15: Global exchange rate factor model - Estimates for emerging Asia (RMB used as regional factor)

\begin{tabular}{|c|c|c|c|c|c|c|}
\hline & Full sample & Before 2005 & After 2005 & $\begin{array}{c}\text { Pre-crisis } \\
\text { (2005/7) } \\
(4)\end{array}$ & $\begin{array}{c}\text { Financial } \\
\text { turmoil } \\
(2007 / 8) \\
(5)\end{array}$ & $\begin{array}{c}\text { Post-crisis } \\
\text { (since 2009) } \\
(6) \\
\end{array}$ \\
\hline Chinese statements & $\begin{array}{r}-0.071^{* *} \\
(0.023)\end{array}$ & $\begin{array}{c}-0.038^{*} \\
(0.020)\end{array}$ & $\begin{array}{r}-0.070^{* *} \\
(0.028)\end{array}$ & $\begin{array}{c}0.074^{*} \\
(0.040)\end{array}$ & $\begin{array}{l}-0.046 * \\
(0.024)\end{array}$ & $\begin{array}{r}-0.149 * * * \\
(0.041)\end{array}$ \\
\hline US factor & $\begin{array}{r}0.697^{* * *} \\
(0.059)\end{array}$ & $\begin{array}{r}0.772^{* * *} \\
(0.051)\end{array}$ & $\begin{array}{r}0.648 * * * \\
(0.068)\end{array}$ & $\begin{array}{r}0.629 * * * \\
(0.087)\end{array}$ & $\begin{array}{r}0.641^{* * *} \\
(0.061)\end{array}$ & $\begin{array}{r}0.698^{* * *} \\
(0.061)\end{array}$ \\
\hline Euro factor & $\begin{array}{r}0.046^{* *} \\
(0.016)\end{array}$ & $\begin{array}{r}0.000 \\
(0.011)\end{array}$ & $\begin{array}{r}0.119 * * * \\
(0.033)\end{array}$ & $\begin{array}{c}0.054^{*} \\
(0.029)\end{array}$ & $\begin{array}{r}0.172 * * * \\
(0.053)\end{array}$ & $\begin{array}{r}0.145^{* *} \\
(0.051)\end{array}$ \\
\hline RMB factor & $\begin{array}{r}0.030 \\
(0.036)\end{array}$ & $\begin{array}{r}0.001 \\
(0.028)\end{array}$ & $\begin{array}{r}0.063 \\
(0.052)\end{array}$ & $\begin{array}{r}0.020 \\
(0.042)\end{array}$ & $\begin{array}{r}0.030 \\
(0.089)\end{array}$ & $\begin{array}{r}0.148 * * \\
(0.053)\end{array}$ \\
\hline Oil prices & $\begin{array}{r}-0.006^{* * *} \\
(0.001)\end{array}$ & $\begin{array}{c}-0.004 * \\
(0.002)\end{array}$ & $\begin{array}{r}-0.003 \\
(0.002)\end{array}$ & $\begin{array}{r}0.001 \\
(0.002)\end{array}$ & $\begin{array}{r}0.003 \\
(0.002)\end{array}$ & $\begin{array}{r}-0.009^{* *} \\
(0.003)\end{array}$ \\
\hline Liquidity risk & $\begin{array}{r}0.158^{* *} \\
(0.061)\end{array}$ & $\begin{array}{c}0.299 * \\
(0.140)\end{array}$ & $\begin{array}{r}0.043 \\
(0.047)\end{array}$ & $\begin{array}{r}0.273 \\
(0.190)\end{array}$ & $\begin{array}{r}0.038 \\
(0.050)\end{array}$ & $\begin{array}{c}1.353^{*} \\
(0.605)\end{array}$ \\
\hline Risk aversion & $\begin{array}{r}0.039 * * * \\
(0.009)\end{array}$ & $\begin{array}{r}0.020^{* * *} \\
(0.005)\end{array}$ & $\begin{array}{r}0.047 * * * \\
(0.012)\end{array}$ & $\begin{array}{r}0.020^{* *} \\
(0.007)\end{array}$ & $\begin{array}{r}0.042^{* * *} \\
(0.012)\end{array}$ & $\begin{array}{r}0.057 * * * \\
(0.016)\end{array}$ \\
\hline Constant & $\begin{array}{r}0.013^{* *} \\
(0.004)\end{array}$ & $\begin{array}{r}0.026^{* * *} \\
(0.008)\end{array}$ & $\begin{array}{r}-0.005 \\
(0.007)\end{array}$ & $\begin{array}{r}-0.027^{* *} \\
(0.008)\end{array}$ & $\begin{array}{r}0.028 \\
(0.019)\end{array}$ & $\begin{array}{r}-0.015 \\
(0.010)\end{array}$ \\
\hline Observations & 18,188 & 10,267 & 7,921 & 2,600 & 2,606 & 2,715 \\
\hline Adjusted $R^{2}$ & 0.200 & 0.186 & 0.245 & 0.281 & 0.229 & 0.262 \\
\hline
\end{tabular}

Note: Pooled OLS estimates of Eq. (2) restricted to emerging Asia and for various sub-periods: (i) before the start of China's exchange rate reform in 2005; (ii) after the start of the reform; (iii) before the eruption of the global financial crisis (2005/7); (iv) during the intensification of the global financial turmoil (2007/08); (v) since the onset of the recovery in emerging Asia (post-2009). The RMB/SDR (orthogonal with respect to both the US and euro factors) is taken here as regional factor. China is excluded from the estimation so as not to have it on both sides of the regression. Robust standard errors are reported in parentheses. $\left({ }^{* *}\right),\left({ }^{* *}\right)$ and $(*)$ denote statistical significance at the $1 \%, 5 \%$ and $10 \%$ level of confidence, respectively.

Table 16: Determinants of the heterogeneity in the elasticity to RMB shocks across countries

\begin{tabular}{|c|c|c|c|c|c|c|c|c|c|}
\hline & $(1)$ & $(2)$ & (3) & $(4)$ & (5) & $(6)$ & $(7)$ & $(8)$ & (9) \\
\hline Exports to China & $\begin{array}{r}0.250^{* * *} \\
(0.073)\end{array}$ & & & & & & $\begin{array}{r}0.099 \\
(0.067)\end{array}$ & & \\
\hline Imports from China & & $\begin{array}{r}0.204^{* * * *} \\
(0.048)\end{array}$ & & & & & & $\begin{array}{r}0.076 \\
(0.053)\end{array}$ & \\
\hline Financial integration with China & & & $\begin{array}{r}0.384 * * * \\
(0.066)\end{array}$ & & & & & & $\begin{array}{r}0.252^{* *} \\
(0.111)\end{array}$ \\
\hline Exchange rate flexibility & & & & $\begin{array}{r}-0.034^{* *} \\
(0.016)\end{array}$ & & & $\begin{array}{r}-0.038^{* *} \\
(0.018)\end{array}$ & $\begin{array}{r}-0.039 * * \\
(0.018)\end{array}$ & $\begin{array}{r}-0.020 \\
(0.021)\end{array}$ \\
\hline Dollar bloc dummy & & & & & $\begin{array}{r}0.090 * * * \\
(0.027)\end{array}$ & & & & \\
\hline Euro bloc dummy & & & & & & $\begin{array}{r}-0.041 \\
(0.033)\end{array}$ & $\begin{array}{r}-0.063^{* *} \\
(0.029)\end{array}$ & $\begin{array}{r}-0.065 * * \\
(0.028)\end{array}$ & $\begin{array}{r}-0.078 * * \\
(0.036)\end{array}$ \\
\hline Constant & $\begin{array}{c}-0.130 * * *-1 \\
\quad(0.016)\end{array}$ & $\begin{array}{r}0.130 * * * \\
(0.016)\end{array}$ & $\begin{array}{r}0.148 * * * \\
(0.017)\end{array}$ & $\begin{array}{r}-0.034 \\
(0.037)\end{array}$ & $\begin{array}{r}0.149 * * * \\
(0.018)\end{array}$ & $\begin{array}{r}-0.111^{* * *} \\
(0.017)\end{array}$ & $\begin{array}{r}-0.017 \\
(0.045)\end{array}$ & $\begin{array}{r}-0.015 \\
(0.045)\end{array}$ & $\begin{array}{r}-0.078 \\
(0.060)\end{array}$ \\
\hline Observations & 46 & 46 & 35 & 48 & 48 & 48 & 46 & 46 & 35 \\
\hline $\begin{array}{l}\text { Adjusted } R^{2} \\
\text { log likelihood }\end{array}$ & $\begin{array}{r}0.0258 \\
40.95\end{array}$ & $\begin{array}{r}0.0142 \\
40.68\end{array}$ & $\begin{array}{r}0.0356 \\
32.84\end{array}$ & $\begin{array}{l}0.130 \\
45.66\end{array}$ & $\begin{array}{l}0.158 \\
46.46\end{array}$ & $\begin{array}{r}0.00604 \\
42.47\end{array}$ & $\begin{array}{l}0.160 \\
45.44\end{array}$ & $\begin{array}{l}0.158 \\
45.38\end{array}$ & $\begin{array}{r}0.0662 \\
34.50\end{array}$ \\
\hline
\end{tabular}

Note: The table reports pooled OLS estimates of the determinants of the heterogeneity in the country-specific elasticities with respect to RMB shocks (Chinese statements on exchange rate and reserve policy) shown in Figure 5 . Robust standard errors are reported in parentheses. $(* * *),(* *)$ and $(*)$ denote statistical significance at the $1 \%$, $5 \%$ and $10 \%$ level of confidence, respectively. 


\section{Appendix A: Additional tables}

\section{Table I: List of the main authors of official statements}

Presidents of the People's Republic of China

- $\quad$ Jiang Zemin: 27 March 1993 - 15 March 2003

- $\quad$ Hu Jintao: since 15 March 2003 - present

List of Premiers of the People's Republic of China

- $\quad$ Li Peng: 1987 - 17 March 1998

- $\quad$ Zhu Rongji: 17 March 1998 - 16 March 2003

- $\quad$ Wen Jiabao: since 16 March 2003

Governor of the People's Bank of China (PBC)

- $\quad$ Dai Xianglong: June 1995 - December 2002

- $\quad$ Zhou Xiaochuan: December 2002 - present

Other PBC officials, Head of State Administration of Foreign Exchange (SAFE) and other Chinese officials (including from China Investment Corporation)

- $\quad$ Various relevant officials

Table II: Selected examples of official statements

\begin{tabular}{|c|c|c|c|c|c|}
\hline \multicolumn{6}{|c|}{ A. Examples of statements on the exchange rate regime } \\
\hline Market impact & $\begin{array}{l}\text { Dummy } \\
\text { value }\end{array}$ & Date & Time & Policy-maker & Statement \\
\hline $\begin{array}{l}\text { US dollar reference is } \\
\text { relaxed to appreciate }\end{array}$ & 1 & 28/08/2005 & 23:48 GMT & $\begin{array}{l}\text { Governor Zhou } \\
\text { (People's Bank of China) }\end{array}$ & $\begin{array}{l}\text { "I think it is very clear that China is introducing a new exchange rate } \\
\text { mechanism. It is not a one-time adjustment." }\end{array}$ \\
\hline $\begin{array}{l}\text { US dollar reference is } \\
\text { maintained }\end{array}$ & 0 & 09/10/2004 & 03:32 GMT & $\begin{array}{l}\text { Prime Minister Wen Jiabao } \\
\text { (China) }\end{array}$ & $\begin{array}{l}\text { "We will take gradual steps towards building a flexible and resilient } \\
\text { exchange system." }\end{array}$ \\
\hline $\begin{array}{l}\text { US dollar reference is } \\
\text { relaxed to depreciate }\end{array}$ & -1 & 08/05/1998 & 02:10 GMT & $\begin{array}{l}\text { Governor Dai } \\
\text { (People's Bank of China) }\end{array}$ & $\begin{array}{l}\text { "We still have enough confidence to say we will be able to maintain a stable } \\
\text { currency... It goes without saying that China has to pay a certain price to } \\
\text { maintain a stable renminbi." }\end{array}$ \\
\hline \multicolumn{6}{|c|}{ B. Examples of statements on reserve composition } \\
\hline Market impact & $\begin{array}{l}\text { Dummy } \\
\text { value }\end{array}$ & Date & Time & Policy-maker & Statement \\
\hline $\begin{array}{l}\text { Diversification out of } \\
\text { the US dollar }\end{array}$ & 1 & 08/01/2002 & 13:32 GMT & $\begin{array}{l}\text { Finance Minister Xiang } \\
\text { Huaicheng (China) }\end{array}$ & $\begin{array}{l}\text { "China has always thought the euro important and thinks that it will some } \\
\text { day be on an equal footing with the U.S. dollar. It is inevitable that the euro } \\
\text { will become some countries' reserve currency." }\end{array}$ \\
\hline $\begin{array}{l}\text { Reserve composition } \\
\text { is maintained }\end{array}$ & 0 & $24 / 03 / 2005$ & 11:52 GMT & $\begin{array}{l}\text { Deputy chief of SAFE Wei } \\
\text { Benhua (China) }\end{array}$ & $\begin{array}{l}\text { "When managing our foreign exchange reserves, we insist on the principle of } \\
\text { safety, liquidity and profitability." }\end{array}$ \\
\hline $\begin{array}{l}\text { Diversification into } \\
\text { the US dollar }\end{array}$ & -1 & 05/03/2006 & 01:25 GMT & $\begin{array}{l}\text { Governor Zhou } \\
\text { (People's Bank of China) }\end{array}$ & $\begin{array}{l}\text { "The forex reserves are still growing. Some people are concerned that the } \\
\text { amount of dollar assets in the reserves will fall. But that is not the case." }\end{array}$ \\
\hline
\end{tabular}

Source: authors' own compilation from Reuters News and Factiva. 
Table III: Selected statistics on the data on official statements

\begin{tabular}{|c|c|c|c|c|c|c|}
\hline & \multicolumn{2}{|l|}{ \# by type: } & & & & \\
\hline & $\begin{array}{r}\text { Exchange rate } \\
\text { regime }\end{array}$ & $\begin{array}{l}\text { FX reserve } \\
\text { composition }\end{array}$ & & & & \\
\hline-1 & 26 & 9 & & & & \\
\hline 0 & 167 & 14 & & & & \\
\hline 1. & 76 & 29 & & & & \\
\hline \multirow[t]{3}{*}{ Total: } & 269 & 52 & & & & \\
\hline & \# by author: & & & & & \\
\hline & $\begin{array}{r}\text { People's Bank } \\
\text { of China } \\
\text { (Governor) }\end{array}$ & $\begin{array}{r}\text { People's Bank } \\
\text { of China } \\
\text { (other official) }\end{array}$ & President & Premier & Head of SAFE & $\begin{array}{r}\text { Other Chinese } \\
\text { official }\end{array}$ \\
\hline-1 & 8 & 3 & 6 & 5 & 1 & 3 \\
\hline 0 & 96 & 11 & 11 & 42 & 18 & 10 \\
\hline 1. & 36 & 8 & 7 & 19 & 5 & 8 \\
\hline Total: & 140 & 22 & 24 & 66 & 24 & 21 \\
\hline
\end{tabular}

Source: authors' own compilation from Reuters News and Factiva. 


\section{Appendix B: Theoretical basis underlying the conditional model}

The theoretical basis for such a model can be found in the microstructure literature of FX markets, and more specifically the literature on announcement effects and asset prices (e.g. Andersen et al. 2003, Blinder et al. 2008). This literature commonly models the exchange rate in a standard asset-pricing framework, where the log exchange rate $s_{t}$ is a function of the discounted value of private sector expectations about future fundamentals $f_{t+i}$ :

$$
s_{t}=(1-\theta) \sum_{i=0}^{\infty} \theta^{i} E_{t}\left(f_{t+i} \mid \Omega_{t}\right)
$$

with $\Omega_{t}$ as the public information available at time $t$, and $\theta$ as the discount factor. Since the objective is to understand the effect of public statements by policy-makers on exchange rates, it is useful to formulate a dynamic specification of this model, which yields

$$
\Delta s_{t}=(1-\theta) \sum_{i=0}^{\infty} \theta^{i}\left[E_{t}\left(f_{t+i} \mid \Omega_{t}\right)-E_{t-1}\left(f_{t+i} \mid \Omega_{t-1}\right)\right]
$$

The implication is that what drives exchange rates are changes to expectations by market participants about relevant future fundamentals. As China's reserve diversification plans and changes in its exchange rate regime may precisely be such fundamentals, along with our three-factor pricing model, our conditional empirical model can be rationalized from this simple, stylized conceptual framework as Eq. (2). 


\section{Appendix C: Additional charts}

Figure C1: China and Germany's relative economic size: now and then

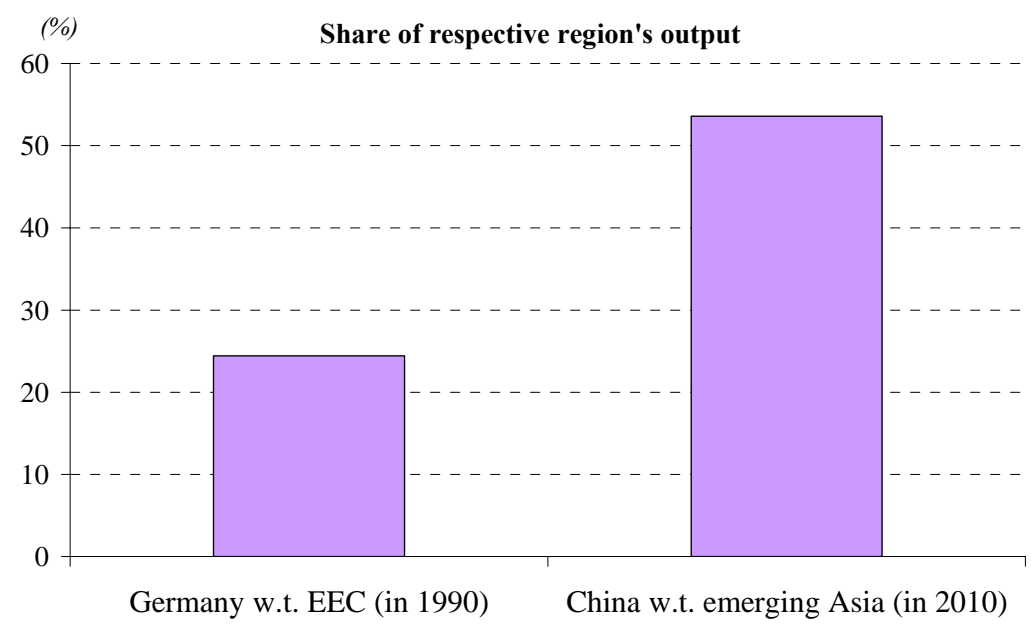

Note $:$ EEC = European Economic Community. Source: IMF World Economic Outlook and authors' calculations.

Figure C2: Germany's role as a regional trading hub back then

Germany's share of bilateral trade (in 1990)

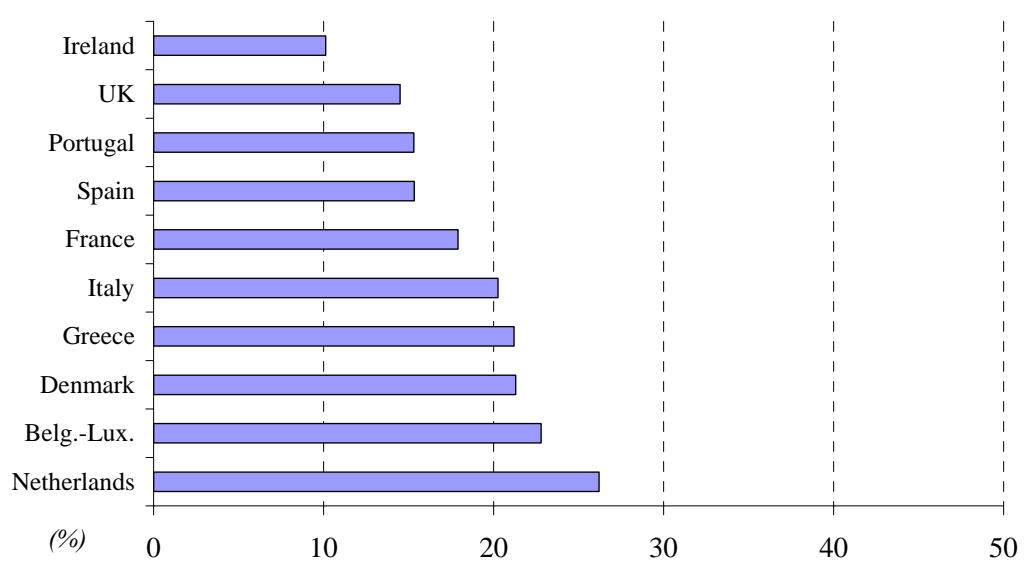

Source: IMF Direction of Trade Statistics and authors’ calculations.

Figure C3: China's role as a regional trading hub now

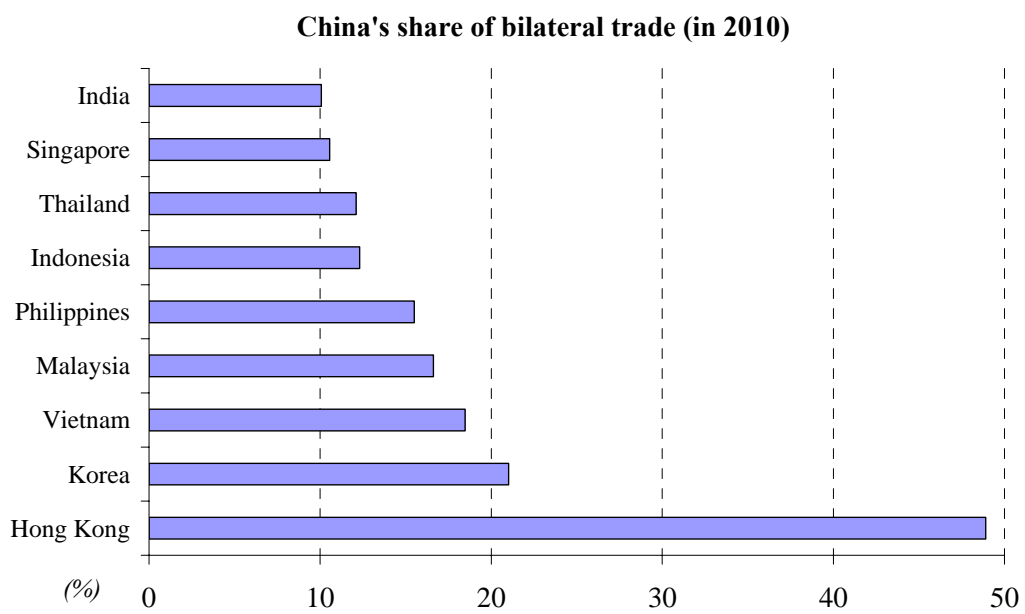

Source: IMF Direction of Trade Statistics and authors’ calculations. 
